\title{
Carl Schmitt - myśliciel walki - czyli precz z fałszywym politycznym liberalnym konsensusem
}

\section{(Carl Schmitt - thinker of fight - that means away from false political liberal consensus)}

\begin{abstract}
In this article I present radical approach to capitalist ideology using intellectual thoughts of Carl Schmitt. I also try to expose this part of his thinking that particularly can help us to understand contradictions of liberalism ideology and also weakness of democratic system. We must to find solution how to transform existing capitalist global regime of inequality and exploitation into more equally and really democratic structure. I assert that in this hard and specific task can help us critical approach toward capitalism, that is represented by many intellectuals from different Scientific disciplines and give us powerful and deep critique of existing regime. The neoliberal ideology try to defame both valuable though of Carl Schmitt and critical approach toward capitalism, but the time has come, new crises that started in 2007 showed the world weakness and bloodthirstiness of capitalist exploitation system. I used Schmitt to explore contradictions of still existing marriage between liberalism and democracy and also to try understand how we can transform this terrible situation into good ending.
\end{abstract}

Keywords: democracy, liberalism, critical approach, revolution, antagonism, politics

\section{Wprowadzenie do Schmittowskiej krytyki liberalnej-demokracji}

Carl Schmitt był i pozostanie myślicielem niezwykłym. Jego wartość dzisiaj polega przede wszystkim na tym, że z ogromną przenikliwością przyjrzał się wszelkim subtelnościom tzw. liberalnej demokracji i pokazał nie dające się pogodzić dwa nurty myślowe lęgnące u jej podstaw. Jeśli spojrzymy na dzisiejszą rzeczywistość europejską to musimy tak czy owak przyznać, że stoimy w obliczu naprawdę niebanalnych problemów. Fale imigrantów napływają na tereny Unii Europejskiej. Odradzają się faszystowsko-narodowe ruchy, a populistyczne prawicowe partie zaczynają odnosić przytłaczające sukcesy. Całą to sytu- 
ację komplikuje światowy kryzys ekonomiczny i polityczny. Rosnące nierówności społeczne, islamski fundamentalizm, zamachy w Paryżu i Londynie, rozpadający się i zarazem coraz bardziej żarłoczny neoliberalizm. Wszystkie te wątki składają się na dość fatalny obraz nie napawający optymizmem. W tym artykule wydobędę te aspekty myśli Schmitta, które jak sądzę, są szczególnie wartościowe dla krytycznego spojrzenia na naturę liberalizmu i obecne w nim założenia, które nie dają się pogodzić z demokratycznym spojrzeniem na rzeczywistość. Ustrój odwołujący się do woli ludu również znajduje się w schyłkowym momencie, a kapitalizm przestał go potrzebować. Nie pretenduję tutaj bynajmniej do całościowego ujęcia myśli Schmitta. Staram się jedynie ukazać jego niesłabnącą atrakcyjność ze względu na rzadko spotykaną jasność i precyzyjność wglądu w naturę rzeczy. Artykuł ten pisany jest z perspektywy radykalnej, która uznaje, że nadszedł już kres obecnego porządku neoliberalnego i jest on jak kolos na glinianych nogach, które mogą się roztrzaskać lada chwila. Jak pisał w swojej analizie Lacana wybitny intelektualista rangi światowej Slavoj Žižek: „Przejdźmy jednak od komedii do tragedii. Czy kiedy upada jakiś reżim polityczny, nie mamy do czynienia z sytuacją, w której podobnie nie sposób odróżnić jego dwóch śmierci - symbolicznej i realnej? Istnieja takie dziwne epoki, gdy dany reżim jeszcze trwa jakiś czas, choć wiadomo, że jego czas minąt. Tak jakby żył on dalej, ponieważ nie zauważył swojej śmierci. Jak pisał Hegel, Napoleon musiat zostać pokonany dwa razy, by to zrozumieć: jego pierwsza klęskę w 1813 roku można było brać jeszcze za zwykly przypadek; dopiero powtórna klęska pod Waterloo dowiodła, że jego odejście wyraża głębsza historyczną konieczność”.

Kres hegemonii neoliberalnej już nastąpił. Kwestią czasu jest kiedy objawi się ona naszym oczom. Narastające niesprawiedliwości społeczne powiązane z rosnącą nieprzerwanie od czasów oświecenia świadomością własnej sytuacji ekonomicznej i politycznej sprawia, że szerokie masy społeczne nie są już tak łatwe do sterowania jak niegdyś, co powoduje konieczność radykalnych działań ze strony elit finansowych w celu zachowania własnej uprzywilejowanej pozycji. Okazuje się, że partiom politycznym w ustroju liberalno-demokratycznym wcale nie chodzi o słuszność własnych argumentów, ani o przekonanie kogokolwiek do nich. Próbują zamiast tego sterować szerokimi masami społecznymi za pomocą podporządkowanych sobie mediów aby zdobyć poparcie większości i sprawować tym samym władzę. Jak pięknie to widać w dzisiejszej polskiej demokracji, gdy dowolna ekipa rządząca dochodzi do władzy, następuje od razu maksymalne zobojętnienie na wcze-

\footnotetext{
${ }^{1}$ Slavoj Žižek, Lacan. Przewodnik Krytyki Politycznej, przeł. J. Kutyła, Wydawnictwo Krytyki Politycznej, Warszawa 2010, Wydanie II rozszerzone, s. 103.
} 
śniejszych wyborców, nagle traktowanych jak nieistotny motłoch, a których znaczenie odżywa (ewentualnie) dopiero podczas następnych wyborów. System konstytucyjny niczym się w praktyce liberalnej nie różni od systemu absolutystycznego - oczywiście nazwa jest inna. „Partie polityczne (o których $w$ tekście konstytucji nie ma ani słowa) nie reprezentuja ścierajacych się ze soba pogląów, lecz sa w praktyce grupami wptywu zorganizowanymi wokół społecznych i gospodarczych interesów. Zawieraja ze sobą praktyczne kompromisy i koalicje, kierujac się własnym interesem, i rozważaja nowe możliwości poszerzania sfer wpływu. Poparcie mas zdobywaja dzięki aparatowi propagandy, który odwoluje się przede wszystkim do konkretnych namacalnych interesów $i$ emocji. Argumenty charakteryzujące prawdziwa dyskusję zanikają zastąione kultura negocjacji oraz celową kalkulacja interesów i szans poszerzenia zakresu władzy, a w partyjnej propagandzie wobec mas plakatowa, agresywna sugestiq"2.

Dzisiejsza demokracja parlamentarna w neoliberalnym społeczeństwie jest satyrą demokracji, jest kpiną z praworządności i wreszcie jest obrazą rozumu każdego przeciętnie inteligentnego obywatela. Przemoc hegemonii neoliberalnej jest jeszcze gorsza niż dawnego państwa absolutystycznego ponieważ jest ukryta. Pod pozorami prawomocnych, demokratycznych rządów kryje się taki sam wyzysk jak uprzednio. Tylko, że tym razem nie jest on taki oczywisty i trudniej go nazwać po imieniu. Dzieje się tak, ponieważ teoretycznie jesteśmy wolni ale praktycznie niewiele się różnimy od dawnych niewolników. W liberalnej demokracji sprzedają nam wolność zniewolenia, a my sami stajemy się mięsem armatnim na łasce korporacyjnych autokratów. Dzisiejsza demokracja to tak naprawdę korpokracja rządzona interesami finansowych lobbystów. Nie może być inaczej ponieważ liberalizm jest oparty na konstytuującym go błędzie. Jest nim przekonanie, że należy wykluczyć antagonizm ze sfery polityczności, co nie jest możliwe gdyż sama natura polityczności oparta jest na antagonizmach i namiętnościach pozwalających oddziaływać i tworzyć tożsamości zbiorowe. Jak pisze Chantal Mouffe jedna z główny kontynuatorek myśli Schmitta: „Polityczność nie może być ujęta przez liberalny racjonalizm, skoro jego spójność wymaga zanegowania nieredukowalności antagonizmu - ten zaś przez liberalizm zanegowany być musi, ponieważ przez podkreślenie nieuchronności momentu decyzji - w mocnym znaczeniu, jako przymusu rozstrzygnięcia w obszarze nierozstrzygalności - obnaża on granice wszelkiego racjonalnego konsensusu. $O$ ile myśl liberalna złączona jest $z$ racjonalizmem $i$ indywiduali-

\footnotetext{
${ }^{2}$ C. Schmitt, Duchowa i historyczna sytuacja dzisiejszego parlamentaryzmu, [w:] Teologia polityczna i inne pisma, przeł. M.A. Cichocki, Wydawnictwo Aletheia, Warszawa 2012, s. 147.
} 
zmem, przejawiana przez nią ślepota na antagonistyczny wymiar polityczności jest nie tyle czysto empiryczną omytką, ile błędem ją konstytuującym”3. (podkreśl. - D.Ch.)

Liberalizm ukrywa antagonistyczny charakter polityczności uniemożliwiając tym samym niższym klasom społecznym konieczność walki o własne interesy. Prowadzi to w konsekwencji do rosnącej stratyfikacji społecznej i wykluczenia z partycypacji we władzy w państwie całych klas społeczeństwa. Jest to niedopuszczalne ponieważ celem każdej prawdziwej demokratycznej polityki jest zaoferowanie ludziom realnej alternatywy wobec panującej sytuacji polityczno-ekonomicznej. Nie może się to dziać w warunkach utajonego istnienia panującej hegemonii neoliberalnej i oferowania pseudowyborów prowadzących do partycypacji we władzy wąskich elit, bez zmiany panującej hegemonii na projekt alternatywny ${ }^{4}$ Taki ukonstytuowany na absurdzie porządek nie może być nazwany demokratycznym ponieważ nawet jego legitymizacja nie jest prawdziwa i wynika z zakrycia samej istoty tego co polityczne. „Można pozbawiony treści i założeń funkcjonalizm zmiennych większości przedstawiać jako „dynamikę”, chociaż brak statyczności i substancji nie musi mieć w sobie jeszcze nic dynamicznego. Jakkolwiek jednak udoskonalać tę indyferentna i neutralna treściowo procedurę $i$ aż do absurdu sprowadzać ja do samego tylko matematyczno-statystycznego ustalania większości - zawsze trzeba będzie przyjmować jedna materialna zasadę sprawiedliwości, jeśli cały system legalności nie ma się załamać w jednej chwili: zasadę, że wszelkie możliwe opinie, kierunki i ruchy mają bezwzględnie taka sama chance uzyskania większości. Bez tej zasady nie tylko większościowa matematyka byłaby z racji swej obojętności na wszelki treściowy wynik groteskowa zabawa, a wywiedzione $z$ niej pojęcie legalności bezczelną kpiną z wszelkiej sprawiedliwości, lecz także już po pierwszej większości byłby koniec z samym systemem, ponieważ pierwsza większość ustanowiłaby się legalnie jako trwała władza. Utrzymywania jednakowej chance nie sposób wyłaczyć $z$ parlamentarnego państwa prawodawczego. Pozostaje ona zasada sprawiedliwości i niezbędna do istnienia maksyma samozachowania. Nawet w petni urzeczywistniony funkcjonalizm czysto arytmetycznych większości nie może zrezygnować z tej niezbędnej przesłanki i podłoża swej legalności”' (podkreśl. - D.Ch.)

Widać w świetle tego znakomitego fragmentu tekstu Schmitta, że jeśli zastosujemy chłodną i rzeczową analizę tego jak demokracja liberalna w parlamentarnym pań-

${ }^{3}$ Ch. Mouffe, Polityczność. Przewodnik Krytyki Politycznej, przeł. J. Erbel, Wydawnictwo Krytyki Politycznej, Warszawa 2008, s. 27.

${ }^{4}$ Ch. Mouffe, Agonistyka. Polityczne myślenie o świecie, przeł. B. Szelewa, Wydawnictwo Krytyki Politycznej, Warszawa 2015, s. 17-32.

${ }^{5}$ C. Schmitt, Legalność i prawomocność, przeł. B. Baran, Wydawnictwo Aletheia, Warszawa 2015, s. 47-48. 
stwie prawa uzasadnia samą siebie, to doznajemy wstrząsu poznawczego. Wynika to z tego, że jeśli zastanowimy się dokładnie nad tym, co pisze Schmitt, wtedy nie możemy mu odmówić racji. Rządy korpokracyjne, które w większości państw Zachodniej Europy są określane demokratycznymi, nie spełniają podstawowych przesłanek postawionych przed systemami mieniącymi się tą nazwą. Wolność indywidualna i święte prawo własności w neoliberalizmie w sposób nieubłagany zaczyna dominować nad suwerenną wolą ludu. Doprowadzając do zaniku jakiegokolwiek jego wpływu na rządy, w imieniu pustej i fikcyjnej, a zatem fałszywej legitymizacji jaką zapewnia sobie liberalna demokracja będąca $\mathrm{w}$ istocie jedynie parodią ustroju jakim miała się mienić. Mamy więc do czynienia z czystym i bezprzykładnym fałszowaniem natury tego co demokratyczne, w którym to precedensie prawo odgrywa rolę służebną wobec panującej grupy interesów. Okazuje się, że system większościowy służy nie tyle wykrywaniu homogenicznej woli ludu, co raczej uprawomocnia tyranię większości nad mniejszością. Trzeba też tutaj wspomnieć o kluczowej roli jaką odgrywa jednakowa chance dla wszystkich zainteresowanych ubieganiem się o partycypowanie we władzy. Widoczne jest, że ten podstawowy warunek o którym wspomina Schmitt nie zostaje spełniony. Co więcej w sposób otwarty i bezczelny urzędujące partie nie wahają się zmieniać ordynacji wyborczej tak, aby w sposób „demokratyczny” doprowadzić do ponownej reelekcji i partycypacji w korzyściach płynących z władzy. Już sama problematyka stanu wyjątkowego jest tu wystarczającą, ponieważ przy jego użyciu można odsunąć na bok wszelkie demokratyczne procedury. Zgodnie ze Schmittem: „Oparta na dysponowaniu osądem, uznaniu legalności $i$ natychmiastowej wykonalności trojaka wielka premia za posiadanie legalnej władzy całe swoje zasadnicze działanie, które odsuwa na bok wszelka ideę jednakowej chance, rozwija przy korzystaniu z nadzwyczajnych uprawnień stanu wyjątkowego. Zapewnia ponadto rzadzacej partii dysponowanie nie tylko „tupem”, spoils w dawnym sensie, lecz takize wraz z prawem podatkowym w kwantytatywnie totalnym państwie dysponowanie całym przychodem krajowym. Wystarczy rozważyć tę stronę legalnych możliwości, by stwierdzić ich wptyw na zasadę legalności parlamentarnego państwa prawodawczego. Do dużej premii dochodza jeszcze pomniejsze. Partia większościowa może np. przed nadchodzącymi wyborami i głosowaniami ustalić regulacje prawa wyborczego korzystne dla siebie i niekorzystne dla konkurenta politycznego"6. (podkreśl. - D.Ch.)

Istotnie partia, która w obecnej neoliberalnej hegemonii wejdzie w konszachty z burżuazyjnymi oligarchami finansowymi ma z reguły zapewnioną reelekcję, ponieważ

\footnotetext{
6 Tamże, s. 59.
} 
wykorzystując wysokie spektrum swoich możliwych oddziaływań jako legalna władza państwowa może praktycznie w sposób nieograniczony manipulować mediami, a tym samym szerokimi masami społecznymi, zawsze zachowując pozory legalności za pomocą zdehumanizowanego prawa. Szczególnie istotna w kontekście polskim wydaje się tu manipulacja regulacjami prawa wyborczego dokonywana w glorii legalizmu państwowego przez partię rządzącą. Z takimi to ekscesami mamy do czynienia choćby na krajowym gruncie, a które to działania osłabiają, a nawet niszczą polską demokrację uprzywilejowując wybraną partię. Wspomina o tym trafnie Bogusław Śliwerski w swoim opus magnum Edukacja (w) polityce. Polityka (w) edukacji: „Niektórzy kłada nacisk na traktowanie demokracji w kategorii legitymizacji władzy uzyskanej w wyniku większości wyborczej, niezależnie od tego, że może o niej zadecydować niewielki odsetek wyborców. Oznacza to, iż o większości - tak jakby największa liczba równała się całości społeczeństwa - rozstrzyga procedura wyborcza i skorzystanie z niej przez obywateli. Tak więc o istnieniu ustroju demokratycznego rozstrzygaja warunki formalne jego ustanowienia. Widzimy jednak, jak od wielu lat w III RP partie rządzące tuż przed końcem kadencji tak zmieniaja procedury wyborcze, aby zapewnić sobie jak największe szanse na powrót jeśli nie do władzy, to chociaż do parlamentu"'.

Polskie władze najwyraźniej kpią sobie z demokracji i nie przejmują się tym, co myślą o nich obywatele. Ponieważ wiedzą, że do drugiej rabacji galicyjskiej nie dojdzie. Raz bo nie mamy żadnego odważnego Jakuba Szeli. Dwa bo uposażenia dla służb porządkowych wszelkiej maści zostały wyraźnie zwiększone. ${ }^{8}$ Widać, że nasz prawicowo populistyczny rząd odkrył wreszcie, że prawdziwa demokracja go raczej nie interesuje, a bardziej demokracja policyjna - czy coś w tym guście. Obywatele, którzy go wybrali muszą się teraz pogodzić z realną możliwością braku ponownych wyborów. Cóż widać, że egzystujemy w rzeczywistości w której tradycyjne ideały rewolucji francuskiej, którymi przypomnę były: wolność, równość, braterstwo są tylko pustymi sloganami (i to z rzadka) dla politycznych demagogów, a wolność jest rozumiana w fałszywym liberalnym sensie tego słowa. Dwa ostatnie z tych haseł, które dla każdego demokratycznego człowieka są czymś bardzo ważnym całkowicie znikły z pola widzenia, a lud jakoś się nie kwapi żeby iść do bram.

\footnotetext{
${ }^{7}$ B. Śliwerski, Edukacja (w) polityce. Polityka (w) edukacji, Oficyna Wydawnicza „Impuls”, Kraków 2015, s. 75.

${ }^{8} \mathrm{http}$ ://biznes.onet.pl/wiadomosci/kraj/beda-podwyzki-dla-funkcjonariuszy-i-pracownikow-sluzb-od-2017-r/ dmv3bn (dostęp 08.04.2017).
} 


\section{Aktualność koncepcji polityczności Schmitta w ukazywaniu słabości hegemonii neo- liberalnej}

Schmitt jest dziś niezwykle aktualnym myślicielem ponieważ jego koncepcja polityczności (nie wspominając jego wspaniałej analizy pojęcia suwerenności, sytuacji stanu wyjątkowego, momentu decyzji, propozycji dyktatury komisarycznej) zakładająca, że konstytutywny charakter dla polityki ma rozróżnienie na przyjaciela i wroga uwydatnia konfliktową naturę konstytuowania się tożsamości zbiorowych, a tym samym odsłania ukrytą strukturę więzi społecznych. Bez niego polityka w znanej nam dziś postaci traci dla nas sens. Decyzja związana z ową relacją jest sednem konstytuującym zasadność politycznego bytu. Jak pisze Schmitt: „Rozróżnienie przyjaciela $i$ wroga nie oznacza wcale, że narody skazane są na wieczna przyjaźń lub wrogość, że neutralność jest niemożliwa albo nie ma politycznego sensu. Również pojęcie neutralności, jak każde pojęcie polityczne, warunkuje ostatecznie realna możliwość jednoczenia się ludzi według podziału na przyjaciela i wroga. Jeżeli na świecie zapanowałby stan powszechnej neutralności, wówczas nie tylko wojna nie miałaby żadnego uzasadnienia, ale także sama idea neutralności straciłaby rację bytu. Podobnie jak każda forma polityki, również polityka unikania walki traci sens, jeśli znika realna możliwość walki. Miarodajna jest tylko możliwość pojawienia się sytuacji rozstrzygajacej, prawdziwej walki, a co za tym idzie decyzji, czy taka sytuacja zaistniała, czy nie".

Kryterium polityczne jest podstawowym dla konstruowania się tożsamości zbiorowych. Bez odróżnienia się od innych demokracja traci sens, ponieważ z założenia jest wspólnotą równych, a żeby mogło zaistnieć takie rozróżnienie muszą też być ci nierówni, ci, którzy znajdują się poza demokratyczną wspólnotą. Nie inaczej jest w Polsce zamiast przekształcać antagonizmy polityczne w mniej szkodliwe i pożyteczne dla demokratycznej wspólnoty agonizmy (Mouffe). Mamy niestety do czynienia z rozgrywaniem społeczeństwa wobec silnych biegunów antagonistycznych, pomiędzy PIS i PO, obrońcami Polski i zdrajcami tzw. polskich wartości. Zamiast więc tworzyć prawdziwe struktury demokratyczne i przekształcać instytucje tak, by służyły ogółowi obywateli, reprodukujemy wciąż stare struktury pseudodemokracji szlacheckiej. ${ }^{10}$ Dalej mamy do czynienia niestety z podziałem bipolarnym, dychotomicznym na chamów i panów, a jako trzeci towarzyszy temu wszystkiemu ksiądz - czyli stan kapłański. Polska mentalność nie uwolniła się wciąż z chłopskiej

\footnotetext{
${ }^{9}$ C. Schmitt, Pojęcie polityczności, [w:] Teologia polityczna i inne pisma, przeł. M.A. Cichocki, Wydawnictwo Aletheia, Warszawa 2012, s. 263.

10 Zob. J. Sowa, Fantomowe ciało króla. Peryferyjne zmagania z nowoczesna formą, UNIVERSITAS, Kraków 2011.
} 
pańszczyzny, co widać w relacjach folwarcznych w których często funkcjonujemy. ${ }^{11}$ Ciągle powielamy ten sam schemat, dzielimy społeczeństwo na dwoje, zamiast się zjednoczyć w ogniu przemian, transformacji w nowe postszlacheckie społeczeństwo jutra. Najgorsze jest to, że obiektem politycznych rozgrywek staje się nawet tak podstawowy dla istnienia społeczeństwa obszar, którym jest edukacja. Indoktrynacja, upolitycznienie, nieliczenie się ze zdaniem obywateli, dogmatyczna struktura to wszystko słabości polskiej oświaty. Jak słusznie zauważa Śliwerski: „Im dłużej udaje się sprawujacym władzę utrzymać rozdrobnienie ugrupowań partyjnych i podział dychotomiczny społeczeństwa na swoich (a więc przyjaciót) i obcych (czyli wrogów), tym silniej wykorzystuje się w różnego typu kampaniach wyborczych edukacje jako idealny środek do manipulacji. Im silniej bowiem jest polska oświata i nauka scentralizowana przez upartyjnienie decyzji władz resortów edukacji i nauki, podporządkowanie ich kryteriom programów politycznych stronnictw, centralne zarządzanie nie tylko ustrojem szkolnym, ale i doborem kadr kierowniczych, tym dłużej będzie miała miejsce w tych dziedzinach zapaść, kryzys i wtórne upolitycznienie życia oraz podejmowanie w instytucjach publicznej edukacji destrukcyjnych decyzji oderwanych od interesów narodowej kultury i ogółu społeczeństwa”"12.

Śliwerski uchwycił w tym fragmencie pewien interesujący aspekt. Otóż antagonistyczny podział społeczeństwa polskiego na przeciwstawne, a wręcz wrogie sobie stronnictwa. Ponadto nieliczenie się polityków z interesami własnych obywateli oraz manipulację różnymi kwestiami podstawowymi dla istnienia społeczeństwa jako takiego, w celu partycypacji w elitach władzy. Jest to niewątpliwie interesujące, ponieważ jeśli spojrzymy na to ze schmittowskiej perspektywy, to widzimy jak pięknie wpisuje się ona w powyższą analizę. Politycy w Polsce nie są zainteresowani wypracowywaniem nowej formy ustrojowej, wprowadzaniem realnej polityki demokratycznej związanej z wyborem prawdziwych alternatyw spomiędzy konkurujących ze sobą projektów hegemonicznych. Zamiast tego korzystają z zapóźnienia intelektualnego i moralnego ${ }^{13}$ polskiego społeczeństwa, w sposób bezczelny i bezprzykładny wykorzystując etyczne kategorie w sferze politycznej.

\footnotetext{
${ }^{11}$ A. Leder, Relacja folwarczna, link do pełnego artykułu na stronie Krytyki Politycznej: http://krytykapolityczna. $\mathrm{pl} / \mathrm{kraj} /$ leder-relacja-folwarczna/ (dostęp 05.04.2017).

12 B. Śliwerski, Edukacja (w) polityce ..., z. cyt., s. 79.

${ }^{13}$ To smutne ale wydaje się, że nadal Polacy nie potrafią poradzić sobie z własnymi uprzedzeniami i to mimo tragicznych wydarzeń drugiej wojny światowej. Może czas już zaakceptować to, że Polacy również mordowali Żydów dla finansowej korzyści, a ci ostatni wnieśli ogromy wkład do dzisiejszej kultury polskiej (choćby Julian Tuwim i Bolesław Leśmian, ale również Bruno Schulz zamordowany podczas II wojny światowej). W kwestii polskich mordów na Żydach: Zob. A. Bikont, My z Jedwabnego, Wydawnictwo Czarne, Wydanie II, Wołowiec 2012. Może w końcu czas zmierzyć się z własną morderczą przeszłością i ją zaakceptować.
} 
Podsycają stare antagonizmy i wzbudzają nowe jedynie po to, aby nie proponując niczego nowego i niczym zasadniczo nie różniąc się od swoich przeciwników, objąć panowanie w rozpadającym się państwie pozostającym pod władaniem hegemonii neoliberalnej. W tym celu zabiegają o poparcie Kościoła Katolickiego z jego rozwiniętą strukturą administracyjną, jak i o innych dowolnych sprzymierzeńców, którym w zamian proponują partycypację w części otrzymanych w wyniku przejęcia władzy zysków.

Dzisiejsza krytyka centralizmu europejskiego jest bardzo podejrzana ponieważ teraz neoliberalizm radzi sobie bardzo dobrze w Chinach, Indiach i innych niedemokratycznych, autorytarnych reżimach. Slavoj Žižek twierdzi, że to nie jest przypadkowe, ten ogólnoświatowy atak na dominujące wartości europejskie, demokrację, prawa człowieka (które w innych kulturach mogą być rozumiane odrębnie itp.), ponieważ neoliberalizm w swojej obecnej formie przestał potrzebować demokracji do własnej egzystencji. ${ }^{14}$ Tym bardziej więc spostrzeżenie Schmitta odnośnie nieprzezwyciężalnych sprzeczności między demokracją i liberalizmem wydają się niezwykle wartościowe i mogą być wskazówką w konstytuowaniu się nowego europejskiego ustroju, w którym demokracja sprzymierzy się zamiast z neoliberalizmem z ruchami takimi jak np. postmarksizm, który twórczo rozwinął myśl Karola Marksa. Nadszedł czas aby demokracja wypowiedziała pakt neoliberalnym siłom i stała się wreszcie wierna egalitarnym ideałom rewolucji francuskiej.

Parlamentaryzm oparty nierozerwalnie na podstawie jaką jest wiara w rządzenie przez dyskusję jest wynalazkiem myśli liberalnej. Jednak przekonanie, że dyskusja rozwiąże wszystkie problemy niewiele ma wspólnego z demokracją. Demokracja masowa nie polega jedynie na takim samym traktowaniu równych obywateli ale i na tym, że wyklucza się z niej wszystkie heterogeniczne elementy, traktując w sposób równie nierówny wszystkich wykluczonych. Siła demokracji według Schmitta polega na ciągłym przezwyciężaniu różnorodnych części zagrażających jednorodnemu charakterowi społeczeństwa: „Wiara w parlamentaryzm, w rządzenie przez dyskusję, charakteryzuje świat myśli liberalnej. Niewiele ma natomiast wspólnego z demokracją. Liberalizm musi zostać oddzielony od demokracji. Wtedy dopiero będziemy mogli dokładnie określić całą złożoną strukturę, wokót której uksztaltowat się fenomen wspótczesnej demokracji masowej. Każda rzeczywista demokracja polega na tym, że nie tylko tych, którzy sa równi, traktuje się w równoprawny sposób, ale również konsekwentnie każdy, kto nie jest zaliczany do równych, podlega różnym

${ }^{14}$ S. Žižek, The Need To Censor Our Dreams, https://www.youtube.com/watch?v=zBbwruvfFR4 (dostęp 08.04.2017). Od ok. 18-21 min. Oczywiście korzystnie jest zobaczyć całość. 
formom nierówności. Demokracja jest więc homogeniczna, a jednocześnie oznacza - z konieczności - wykluczenie lub unicestwienie wszystkich heterogenicznych elementów. (...) Polityczna siła demokracji polega właśnie na zdolności do przezwyciężania i usuwania elementów obcości i nierówności zagrażających homogenicznemu charakterowi demokratycznego społeczeństwa"15. (podkreśl. D.Ch.)

Demokracja w takim rozumieniu w sposób oczywisty nie może wiecznie trwać złączona z liberalizmem, gdyż każde wypływa ze sprzecznej natury przesłanek. Parlamentaryzm wierzy, że zawsze można dojść do porozumienia, że indywidualna wolność i prywatna własność jednostki jest ponad tym, co wspólnotowe, egalitarne. W związku z tym wytwarza się w pewnym momencie nieprzezwyciężalna polaryzacja tych dwóch dążeń. Z jednej strony demokratycznego dążenia do jednorodności i równości wszystkich obywateli, a z drugiej liberalny kult własności i jednostki. Doprowadza to do narastającego antagonizmu, który w końcu musi spowodować rozpad tego skonfliktowanego małżeństwa. Jeśli interpretujemy demokrację i liberalizm w schmittowski sposób ciekawie zarysowuje się kwestia imigrantów/uchodźców. Schmitt dopuszcza pewien konieczny pluralizm ${ }^{16}$ w ramach państwa, jednak nie taki, który zagrażałby jego homogeniczności. W związku z tym obstawałby zapewne za tym, żeby jeśli już w ogóle przyjmować imigrantów, to tylko taką ilość jaka nie zagrażałaby rozpadowi wspólnoty demokratycznej. Ale jaka to ilość? Poza tym rysuje się też tu wyraźnie kwestia: czy imigranci/uchodźcy mają takie same prawo do partycypowania w społeczności wobec której są zewnętrznym, heterogenicznym elementem. Jeśli tak to na pewno musieliby stosować się do norm i zwyczajów panujący w danej, suwerennej wspólnocie. Sprawa nie jest więc taka prosta jakby się na początku zdawało. Jeśli ktoś żąda od nas szacunku pomimo swej odmienności i braku wpasowania w nasze schematy kulturowe, a sam odmawia nam tego samego prawa w stosunku do siebie, to wtedy stajemy przed trudną kwestią określenia granic naszej tolerancji. Istnieją bariery we wzajemnym porozumieniu, których nie da się przekroczyć. Bezkrytyczne respektowanie obcych kultur też może się dla nas źle skończyć. Zamiast je gloryfikować wypada się zastanowić jak, i czy w ogóle się da pogodzić takie sprzeczne dążenia. Muzułmanin kompletnie wyklucza w sposób antagonistyczny w swoim obszarze świadomościowym i społecznym człowieka, który kompletnie odrzuca religię. Dla jego homogeniczno-

${ }^{15}$ C. Schmitt, Duchowa i historyczna sytuacja dzisiejszego parlamentaryzmu, [w:] Teologia polityczna $i$ inne pisma, przeł. M.A. Cichocki, Wydawnictwo Aletheia, Warszawa 2012, s. 150-151.

${ }^{16}$ Generalnie pluralizm jest rozumiany u niego jako zagrożenie homogeniczności narodu i w konsekwencji możliwość rozpadu państwa. 
ści zarówno wewnętrznej jak i zewnętrznej nie jest możliwe zaakceptowanie absolutnego ateizmu mieszkańca wysoko rozwiniętych społeczeństw Zachodniej Europy. Tych dwóch sprzeczności nie da się pogodzić. Ten przypadek pokazuje, że konieczne jest rozróżnienie pomiędzy tym co jest dopuszczalne, a co nie w naszej kulturze i społeczeństwie. Ustanowienie granic światopoglądowych, których nie da się przekroczyć, inaczej grozi nam rozpad suwerennego, demokratycznego państwa.

Każda władza państwowa zostaje ustanowiona przez pewien konkretny podmiot. U podłoża każdego porządku prawnego leży więc suwerenna decyzja o jego ustanowieniu. Nie da się uciec od tego konstytutywnego dla każdej formy państwowości elementu. Liberalizm w sposób nieprawdziwy przenosi ciężar ustanawiania państwa z suwerennej decyzji na prawną legislaturę. Lud zostaje odsunięty na bok i zmarginalizowany, podporządkowany formalnym zasadom prawnym, choć jak wiadomo to jego suwerenna wola decyduje o samym zaistnieniu państwa jako takiego. W liberalnej demokracji wola ludu zostaje sprowadzona do pustej i stosunkowo bezzasadnej woli większości, która jest dodatkowo ograniczana przepisami prawnymi, na które decydujący wpływ mają elity polityczne i finansowe. Zakłamana pozostaje więc pierwotna natura samego ustanowionego tutaj zgromadzenia, którym jest zewnętrzna wobec prawa konkretna decyzja. To siła leżąca u podstaw owej suwerennej decyzji stanowi o istnieniu państwa jako takiego. Bez mocy politycznej nie można zagwarantować przetrwania jakiejkolwiek konstytucji. To lud poza granicami prawa może dokonywać dowolnych zmian w istniejącym państwie, ponieważ to on jest suwerennym podmiotem, który legnie u jego podstaw. To suwerenność jest kwestią podstawową w ustanowieniu jakiegoś nowego porządku, a nie konstytucja albo przepisy prawa. Jak pisze Paul Hirst: „Klasyczny liberalizm pociaga za soba bardzo konserwatywna wersję rzadów prawa i suwerenność ograniczona fundującym aktem politycznym, który nie jest przedmiotem zwykłej polityki. Demokracja zagraża parlamentarno-konstytucyjnemu reżimowi roszczeniem "ludu” do nieograniczonej władzy suwerennej. Widać zatem, że wszystkie porządki prawne mają swoje „zewnętrze”; zależą od warunków politycznych, które sq pierwotne wobec prawa i nie podlegaja prawu. Konstytucja może przetrwać tylko jeśli fundujacy akt polityczny jest wspierany przez jakaśs siłę polityczna. „Lud” istnieje tylko wżadaniach tej skromnej mniejszości (jego „przedstawicieli”), która funkcjonuje jako „większość” w zgromadzeniu ustawodawczym. „Suwerennośc” nie jest zatem kwestia formalnej doktryny konstytucyjnej lub zasadniczo nieszczerych odwołań do „ludu”; jest kwestiq określenia, który 
konkretny podmiot ma zdolność, poza granicami prawa, do narzucenia porządku, który jako polityczny - może zostać uprawomocniony"17.

Demokracja liberalna zakłamuje więc samą swoją demokratyczną naturę wpierając szerokim masom społecznym, że są reprezentowane podczas, gdy utraciły one możliwość jakiejkolwiek sensownej kontroli istniejącego porządku, w którym są stopniowo ograniczane i szykanowane odpowiednimi ustawami i przepisami prawa. Mogą tylko wyartykułować własną złość za pomocą marszów i pokojowych demonstracji, które nie wnoszą nic nowego do codziennej rzeczywistości, będąc ewentualnym materiałem do wspominek na starość. Brak oficjalnego wsparcia, projektu reform i transformacji istniejących instytucji, niechęć do przemocy, realnej walki i rzeczywistego partycypowania mas, ograniczonych do pacyfistycznego oporu klasy średniej czyni z takich inicjatyw protestacyjnych (np. KOD - Komitet Obrony Demokracji w Polsce $)^{18}$ typową dla neoliberalizmu formę pseudooporu wywołującego uśmiech pobłażania na twarzach polityków świadomych tego, że takie akcje nie są w stanie wywołać zmiany istniejącego porządku rzeczy, zmiany dominującej neoliberalnej hegemonii. Pozwolę sobie na stwierdzenie, że owe demonstracje przebiegają dokładnie w ramach kapitalistycznego systemu nie proponując jego zmiany, a jedynie dając wyraz swemu oburzeniu w obliczu łamania jego zasad. Nie rozumieją więc tego, że to co się dzieje nie wynika jedynie z niedoskonałości rządzących ale ze słabości samego neoliberalnego porządku rzeczy. Chcą zmieniać system za pomocą jego odrzucenia nie proponując żadnych alternatywnych działań, a to na dłuższą metę nie przyniesie skutków. Jak zauważa bułgarski politolog Iwan Krastew: „Dzisiejsze masowe protesty to w pewnym sensie działania w poszukiwaniu pojęć; można je nazwać praktyka bez teorii. Sa najbardziej dramatycznym wyrazem przekonania, że elity nie rządza w interesie ludzi, a wyborcy stracili kontrole nad wybieranymi. Wspieraja insurekcje przeciwko instytucjom demokracji reprezentacyjnej, nie oferując jednak żadnych alternatyw (czy nawet otwarcia na akceptacje jakichś jej niedemokratycznych zamienników). Ta nowa fala protestów jest pozbawiona liderów nie dlatego, że media społecznościowe uczynity rewolucję bez liderów możliwa (o ile nam wiadomo, w starożytnym Rzymie też nie byto internetu), lecz dlatego, że ambicja zakwestionowania wszelkich form politycznej reprezentacji uczyniła liderów politycznych niepoża-

\footnotetext{
${ }^{17}$ P. Hirst, Decyzjonizm Carla Schmitta, [w:] Carl Schmitt. Wyzwanie polityczności, red. Ch. Mouffe, Wydawnictwo Krytyki Politycznej, Warszawa 2011, s. 18-19.

${ }^{18}$ Najgorsze jest to, że ci ludzie organizując się wejdą w późniejsze elity władzy mimo, że nie posiadają żadnej wiedzy politycznej. Zostaną więc łatwo wykorzystani przez partie mające dobre zaplecze intelektualne i instytucjonalne. Często więc będzie to zamienianie złego na jeszcze gorsze.
} 
danymi”19. Absurdalność takich działań, pozbawionych postulatów, które godzą w obecnie ustanowiony porządek hegemoniczny i ich niechęć do tradycji postmarksistowskiej i marksistowskiej oraz powiązania w odmienny projekt hegemoniczny żądań różnych klas społecznych, a nie tylko przedstawicieli klasy średniej powoduje, że ich efekty rozmywają się z momentem powrotu do domów ludzi w nie zaangażowanych. Ta polityka politycznego performens pozbawiona jest zasadniczo celu. Lepiej już swe działania przeprowadzają polscy górnicy.

\section{Wewnętrzne sprzeczności liberalnej-demokracji czyli jak fałszywy liberalny konsensus doprowadza do atrofii polityczności}

Dopiero w doktrynie Schmitta widać nieprzezwyciężalne sprzeczności, w których okowach trwa liberalna myśl. Czyni ona z całej polityki wielki klub dyskusyjny, który chce odroczyć w nieskończoność jakąkolwiek perspektywę krwawej walki. Przekonanie, że prawda objawi się w wyniku racjonalnej dyskusji pomimo tego, że wszystko podporządkowane jest logice pieniądza jest jednak chybione. Rewolucja francuska pokazała, że o własną godność i wartość trzeba potrafić się upomnieć i że nikt nie zrobi tego za nas. Francuzi wiedzą, że aby dostać co się im należy, muszą się o to domagać i nie należy wcale przy tym unikać przemocy. Co z tego, że większość jest przeciw liberalnym reformom skoro parlamentarna mniejszość nie zwraca na to uwagi, pozostaje tylko wziąć sprawy we własny ręce, bo państwo jest dla ludzi, a nie dla ich neoliberalnych oprawców. I to wola suwerennego ludu (Francuskiego, Polskiego itp.) powinna się liczyć, a nie wola jego politycznych i finansowych grabarzy. Słusznie Schmitt pisał: „Istota liberalizmu jest bowiem mediacja, wyczekująca połowiczność, nadzieja, że decydujące rozstrzygnięcie, krwawa ostateczna bitwe można przekształcić w parlamentarnq debatę, odroczyć na zawsze dzięki niekończącej się dyskusji”20.

Jak widać w przypadku Francji, która jest narodem mężnych ludzi nie chcą oni pozwolić na racjonalną dyskusję i powszechne porozumienie w kwestiach dotyczących ich codziennego życia. W całej Francji wybuchają więc walki. Okazuje się, że lud chce mieć coś do powiedzenia i, że nie dopuszczony do głosu za pomocą skutecznych sposobów agonistycznej partycypacji potrafi upuścić władzy krwi. W demokracji liberalnej nierówności są codziennym chlebem ludzi pracy. Święte prawo własności jest najważniejsze, a indywi-

\footnotetext{
${ }^{19}$ I. Krastew, Demokracja: przepraszamy za usterki, przeł. M. Sutowski, Warszawa 2015, s. 75.

${ }^{20}$ C. Schmitt, Teologia polityczna. Cztery rozdziały poświęcone nauce o suwerenności, [w:] Teologia polityczna i inne pisma, przeł. M.A. Cichocki, Wydawnictwo Aletheia, Warszawa 2012, s. 101.
} 
dualny sukces uprawomocnia do wyzysku ludzi ubogich nie posiadających wykształcenia ani własnego kapitału: „Liberalna burżuazja pragnie więc Boga, ale takiego, który pozostaje bierny; chce monarchy, ale pozbawionego władzy; domaga się wolności i równości, a jednocześnie ograniczenia prawa wyborczego do klas posiadających (aby zachować wplyw własności i wykształcenia na prawodawstwo, tak jakby wykształcenie i własność dawały komukolwiek prawo uciskania ludzi ubogich i niewykształconych); niszczy arystokrację krwi i rodu, a jednocześnie toleruje bezwstydny arystokratyzm pieniądza, a więc najgorsza i najgłupsza formę elitaryzmu; nie opowiada się ani po stronie suwerenności króla, ani ludu. Czego więc chce liberalna burżuazja?"21.

Może neoliberałowie niedługo znowu spróbują ograniczyć prawa wyborcze ludziom, choć teraz już nie jest to nawet konieczne, ponieważ coraz mniej obywateli korzysta z tego wywalczonego własną krwią prawa. Jeśli to zostanie uczynione mogą nawet tego nie zauważyć lub zgodnie z logiką biernego oporu wyjdą jedynie na ulice miast i pomaszerują trochę wymachując flagami Unii Europejskiej. Nawet w komunizmie istniało odwołanie do takich wartości jak równość i braterstwo wszystkich ludzi. Można więc było się odnieść do idei powszechnego egalitaryzmu, w liberalnej demokracji nawet to nie jest możliwe. Wszystkie dobrodziejstwa państwa socjalnego i związków zawodowych są niczym innym jak owocem długoletnich walk socjalistów. Trzeba o tym zawsze pamiętać, że to co wywalczone dziś jutro może być utracone w neoliberalnej hegemonii opartej na wyzysku licznych przez nielicznych.

To co niebezpieczne w myśli Schmitta stanowi jego ciągłe podkreślanie roli zewnętrzności antagonizmu, utrzymania porządku w państwie nawet za cenę wprowadzenia dyktatury. Rozumienie polityczności jako nierozerwalnie powiązanej z konfliktem nie do pogodzenia między przyjacielem, a wrogiem, bronienia porządku państwowego za wszelką cenę, prowadzi w konsekwencji do militaryzacji polityki. Co więcej eksponowanie zewnętrznej formy antagonizmu, a nie jego wewnętrznych przejawów może skutkować doprowadzeniem konfliktu politycznego do skrajności i w konsekwencji do zbrojnej walki. Dla tak pojętej polityczności zachowanie homogeniczności państwa nawet za cenę zbrojnych, okrutnych działań jest priorytetem ponieważ nie można dopuścić do tego aby zanikł jednorodny charakter wspólnoty narodowej. Jakikolwiek pluralizm w takiej sytuacji jawi się jako duży problem, a miara tego, co dopuszczalne w ramach tak pojętego społeczeństwa jest zawsze niepewna. Zawsze istnieje więc możliwość ostrego konfliktu i związanego z tym

21 Tamże, s. 98. 
stanu wyjątkowego, podczas którego niemal wszystkie środki są dopuszczalne. Taka ultrapolityka w wykonaniu współczesnych państw np. europejskich mogłaby w rezultacie doprowadzić do eskalacji zbrojnych działań. Rozsądne wydaje się więc jednak dopuszczenie pewnego pluralizmu w państwie i rozładowywanie go za pomocą agonistycznych praktyk (Mouffe). Takie działanie demokratyczne skupiające się na wewnętrznych antagonizmach danego państwa, a nie na zewnętrznych zagrożeniach dla jego jednorodności wydaje się więc jak najbardziej godne rozważenia. Jak świetnie ujmuje to Žižek: „Jak sytuuje się myśl Schmitta wobec wymienionych powyżej różnych strategii wyparcia polityki? Nie tylko nie jest ona w stanie oddać właściwego wymiaru tego, co polityczne, ale - co więcej - tworzy najbardziej podstępną i radykalna formę wyparcia, która pozwolimy sobie tu nazwać ultrapolityką: depolitycyzująca konflikt polityczny poprzez doprowadzenie go do skrajności, przez bezpośrednia militaryzacje polityki. W tej formie, „wyparte” polityczne powraca w postaci próby rozwiązania impasu konfliktu poprzez jego fałszywa radykalizację. Konflikt polityczny zmienia się w efekcie w wojnę między "My" a „Oni” - w wojnę z wrogiem, z którym nie jesteśmy w stanie toczyć symbolicznej walki - nie istnieje bowiem wspólna obu stronom płaszczyzna porozumienia. To symptomatyczne, że radykalna Prawica zwykła mówić o wojnie klas (bądź płci), nie ich walce. Innym wyraźnym wskaźnikiem ultrapolitycznego wyparcia właściwej polityki jest pierwszeństwo, jakie daje polityce zewnętrznej (relacjom między suwerennymi państwami) w stosunku do polityki wewnętrznej (antagonizmom w obrębie społeczeństwa).

\section{Czy relacja do zewnętrznego Innego jako wroga nie jest sposobem wyparcia wewnętrznej} walki, która rozdziera ciało społeczne? W opozycji do Schmitta, lewica powinna uznawać bezwarunkowy prymat wewnętrznego antagonizmu jako konstytutywnego dla polityczności”22. (podkreśl. -D. Ch.)

To niezwykle istotne spostrzeżenie Žižka godne jest zapamiętania, ponieważ pokazuje jak wyparcie, zaprzeczenie tego co polityczne prowadzi do jego nawrotu, w najgorszej z możliwych postaci. Warto jednak pamiętać, że to trafne wejrzenie w naturę zjawiska nie likwiduje z miejsca niezwykłej precyzji z jaką Schmitt ukazuje sprzeczności rysujące się pomiędzy demokracją, a liberalizmem jako dwoma odrębnymi tradycjami intelektualnymi, których koegzystencja przez dłuższy czas nie jest możliwa. Tak więc nawet jeśli Schmitt jest w swych niektórych spostrzeżeniach zbyt radykalny, a może i błędny, nie umniejsza to wartości jego dorobku intelektualnego.

\footnotetext{
${ }^{22}$ S. Žižek, Carl Schmitt w czasach postpolityki, [w:] Carl Schmitt. Wyzwanie polityczności, red. Ch. Mouffe, Wydawnictwo Krytyki Politycznej, Warszawa 2011, s. 41.
} 


\section{$6 / 2017$}

Bardzo ważne jest spostrzeżenie tego, że chociaż demokracja zakłada istnienie równych wobec siebie obywateli, jednak z samą prezentowaną przez nią ideą równości musi powstać nierówność jako taka. Dzieje się tak ponieważ każda zbiorowość konstytuuje się wobec swojego zewnętrza, które jest potrzebne, aby można było się określić i zyskać zbiorową tożsamość. Demokracja wymaga więc dla samej zasadności swego istnienia nierówności jako takich. Oparte na rządach ludu państwo nie ma np. problemu żeby de facto wykluczyć część swych obywateli z życia politycznego lub nawet odebrać im prawo wyborcze, czyniąc ich niewolnikami, ewentualnie obywatelami niepełnej kategorii. Tak jak w dzisiejszej Polsce (nie ma się czego bać, jeśli coś się stwierdza, to się to obnaża, a w samym akcie ujawnienia ukryte jest jądro wyzwolenia) uważa się za obywateli drugiej kategorii tych niebędących wyznawcami religii katolickiej, a zwłaszcza ludność pochodzenia ukraińskiego, białoruskiego, jak i imigrantów/uchodźców. Choć jeszcze nie odebrano tym z nich, którzy posiadają polskie obywatelstwo praw wyborczych. Demokracja nie ma więc problemu $\mathrm{z}$ wykluczaniem ponieważ jest ono konstytutywne dla jej istnienia ${ }^{23}$.

Istotnie jeśli demokracja opiera się na wykluczeniu części zewnętrznej, to wypadałoby zadbać o to, żeby chociaż częściowo w obrębie jednego państwa umożliwiło się agonistyczną partycypację wszystkich egzystujących w nim grup, oprócz tego próbując zawiązywać klasowe sojusze. Nawet jeśli stanowisko Schmitta jest zbyt radykalne, to wydaje mi się po części prawdziwe. Powszechne i równe prawo wyborcze nie wykracza poza granice homogenicznej grupy równych sobie ludzi. Twierdzenie, że każdy człowiek właśnie ze względu na swoje człowieczeństwo jest równy innym jednostkom nie jest twierdzeniem wywodzącym się z demokracji lecz z liberalizmu i zafałszowuje jej prawdziwy charakter. Bowiem nie istnieje coś takiego jak demokracja powszechna, oparta na uznawaniu człowieczeństwa każdego ze swych obywateli. Jest to fikcją choćby ze względu na istnienie $\mathrm{z}$ reguły homogenicznych państw narodowych. W obrębie każdego z rządów ludu nie każdy może mienić się równym obywatelem. Można tu wymienić choćby Stany Zjednoczone Ameryki i ich dobrze znany (McLaren, Giroux) stosunek do ludności kolorowej, a przecież USA jest uznawane za krzewiciela i ojca demokracji w nowoczesnym sensie tego słowa. Zgodnie ze Schmittem: „Logika wskazuje, że powszechne i równe prawo wyborcze i prawo głosu sa tylko skutkiem substancjalnej równości w kręgu równych sobie ludzi i nie wykraczaja poza te granice. Takie równe prawo ma sens tam, gdzie panuje homogeniczność. Natomiast

\footnotetext{
${ }^{23}$ C. Schmitt, Duchowa i historyczna sytuacja dzisiejszego parlamentaryzmu, [w:] Teologia polityczna $i$ inne pisma, przeł. M.A. Cichocki, Wydawnictwo Aletheia, Warszawa 2012, s. 151-152.
} 
powszechny charakter prawa wyborczego, na który zwracaja uwagę zwolennicy „powszechnie przyjętego" rozumienia demokracji, oznacza coś zupełnie innego: każdy dorosły człowiek, właśnie ze względu na swoje człowieczeństwo, jest eo ipso politycznie równy wszystkim innym ludziom. Taki punkt widzenia nie charakteryzuje jednak demokracji, lecz liberalizm i zastępuje demokracją ludzkości dotychczasową demokrację opartą na koncepcji substancjalnej równości i homogeniczności. Tymczasem taka powszechna demokracja obejmująca całą ludzkość nie istnieje - już choćby dlatego, że świat składa się z państw, i to najczęściej nawet państw homogenicznych narodowo. Państwo buduje demokracje właśnie na fundamencie swej narodowej jedności. Dlatego nie każdy może być jego równoprawnym obywatelem"24. (podkreśl.- D. Ch.)

Schmitt rozdziela w swojej twórczości liberalizm i demokrację, pokazuje, że są to dwa odrębne sposoby myślenia o otaczającym nas świecie. Co więcej różnią się one w zasadniczych punktach. Liberalna wiara w powszechny konsensus jest nieadekwatnym pojmowaniem polityczności, a jego przywiązanie do wolności jednostki pojmuje ową ideę w ściśle kapitalistyczny sposób widzenia, który zakłada, że wszyscy mamy takie same szanse na odniesienie sukcesu - co nie jest prawdą. ${ }^{25}$ Takie rozumienie tej jednej z trzech wielkich idei rewolucji francuskiej zawęża ją do ściśle egoistycznego i narcystycznego punktu widzenia, w którym owa wolność istnieje jedynie w ściśle określonych granicach wyznaczonych przez ekonomię i prawo. Natomiast nie zawiera w sobie pola na kwestionowanie otaczających nas struktur władzy i zmienianie samego sposobu w jaki widzimy społeczną rzeczywistość. Jest to więc wolność zniewolenia ${ }^{26}$ przejawiającego się niemożliwością kwestionowania raz ustanowionych reguł rynku, a przede wszystkim jego świętości - własności

\footnotetext{
${ }^{24}$ Tamże, s. $152-153$.

${ }^{25}$ Jest to z gruntu fałszywy liberalny punkt widzenia. Wystarczy tylko tu zauważyć, że choćby kapitał początkowy każdego człowieka jest inny.

${ }^{26}$ Jak twierdził L.A. Blanqui (ur. 8 lutego 1805 w Puget-Théniers, zm. 1 stycznia 1881 w Paryżu). Francuski działacz socjalistyczny i przywódca rewolucyjny. Twórca teorii zwanej blankizmem: „Zarzuca się komunizmowi, że poświęca jednostkę i że jest negacją wolności. (...) I w czyim to imieniu wysuwa się te obraźliwe przypuszczenia? $\mathrm{W}$ imieniu indywidualizmu, który od tysięcy lat nieustannie zabija i wolność, i jednostkę. Czy wiele jest jednostek naszego gatunku, z których indywidualizm nie uczynił niewolników i ofiar? Może jedna na dziesięć tysięcy. Dziesięć tysięcy ofiar na jednego oprawcę! Dziesięć tysięcy niewolników na jednego tyrana! I śmie się wygłaszać tyrady w obronie wolności! Rozumiem. Ponura obłuda kryje się za tą maskaradą. Oligarchia nazywa siebie demokracją, krzywoprzysięstwo - uczciwością, mord - umiarem. Znamy ją, tę wolność, która występuje przeciwko komunizmowi - jest to wolność ciemiężenia, wolność eksploatowania bez pardonu, wolność dla możnych tego świata, którym - jak mówi Renan - tłumy służą za podnóżek. Tę właśnie wolność lud nazywa uciskiem i zbrodnią. Nie chce jej dłużej karmić swym ciałem, swoją krwią". Zob.: L.A. Blanqui, Krytyka społeczna, [w] Wybór pism, przeł. I. Bibrowska, B. Wścieklica, red. A. Baranowska, RSW „Prasa”, „Książka i Wiedza”, Warszawa 1975, s. 333-334.
} 
prywatnej. Stoi to w całkowitej kolizji z zasadą równości i braterstwa ale to już kapitalizmu nie interesuje, gdyż immanentnym elementem tego systemu jest narastanie nierówności i brak solidarności międzyludzkiej. ${ }^{27}$ Schmitt ma nam jeszcze wiele do powiedzenia. Jego radykalizacja polityczności uwidacznia sposób w jaki jej wykluczenie, przeniesienie do sfery ultrapolityki skutkuje jej radykalizacją i ustanowieniem się nieprzezwyciężalnego przeciwieństwa między przyjacielem a wrogiem. Nie można sprowadzać polityczności do partykularyzmu poszczególnych jednostek odmawiając im uczestniczenia w uniwersalności. Są to dwa współistotne wymiary politycznej gry. Rozwiązaniem nie jest tutaj powszechna tolerancja i nawoływanie do zrozumienia i akceptacji. Należy uwolnić prawdziwy uniwersalny wymiar polityczności poprzez odmienne jego rozumienie jako walki na rzecz prawdy, której się służy: „Czy wszystko to oznacza, że w naszych postpolitycznych czasach Schmitt nie ma nam już nam nic ważnego do powiedzenia? Wręcz przeciwnie: odniesienie do Schmitta jest kluczowe dla zrozumienia impasu, w jakim znalazła się postpolityczna liberalna tolerancja. Schmittowska ultrapolityka - radykalizacja polityki do punktu, w którym staje się ona otwarta wojna Nas przeciwko Nim, widoczna w różnych postaciach fundamentalizmu - jest forma, jaka przyjmuje wykluczona polityczność, wracając do postpolitycznego uniwersum pluralistycznych negocjacji i konsensualnej regulacji. Z tego właśnie powodu jedynym sposobem, by przeciwstawić się wybuchom ultrapolityki, nie jest „więcej tolerancji”, „więcej współczucia” $i$ „wielokulturowe porozumienie”, ale wręcz przeciwnie - powrót właściwej polityki, uznanie na powrót właściwego wymiaru polityczności, z którego uniwersalność nie jest wykluczona, lecz z którym jest wspótistotna. To punkt wyjścia dla konstruowania prawdziwie lewicowej postawy, która przeciwstawia się prawicowej polityce utwierdzania partykularnych tożsamości. Chodzi w niej o utożsamienie uniwersalizmu z bojowa i rodząca podziały pozycją zaangażowania. Otóż prawdziwi uniwersaliści to nie ci, którzy głoszą globalne poszanowanie odmienności i wszechogarniająca jedność - przeciwnie - to ci, którzy angażują się w żarliwą walkę o uznanie Prawdy, której służą"28. (podkreśl.D.Ch.)

\footnotetext{
${ }^{27}$ Potwierdzenia nie trzeba daleko szukać. Laureat Nagrody Banku Szwecji im. Alfreda Nobla w dziedzinie ekonomii J. E. Stiglitz w przedmowie do książki Cena nierówności w jaki sposób dzisiejsze podziały społeczne zagrażaja naszej przyszłości, Krytyka Polityczna, Warszawa 2015, loc 692, wersja mobi. Pisze: Ułomności systemów politycznego i gospodarczego są ze sobą związane i kumulują się. System polityczny wzmacniający głos bogatych stwarza wiele okazji do takiego kształtowania praw i regulacji - i takiego ich egzekwowania - by nie chroniły one zwykłych obywateli przed bogatymi, a wręcz pozwalały bogatym bogacić się jeszcze bardziej kosztem reszty społeczeństwa".

${ }^{28}$ S. Žižek, Carl Schmitt w czasach postpolityki, [w:] Carl Schmitt. Wyzwanie polityczności, red. Ch. Mouffe, Wydawnictwo Krytyki Politycznej, Warszawa 2011, s. 48-49.
} 
Prawdziwie uniwersalistyczna postawa zakłada więc zaangażowanie i walkę w obronie sprawy, której się wierzy, nawet jeśli wzbudza to podziały. Nieprawdą są głoszone pochopnie hasła wielkiej jedności całego świata. Odwołujące się do idei ludzkości itp. Jest to wielka liberalna fikcja, która z całego świata chce uczynić forum dyskusyjne rynkowych prozelitów. Nawet pojęcie świata jest niczym więcej jak manifestacją absurdalnych żądań Zachodu i wielkich mocarstw do tworzenia złudzenia globalnej polityki, podczas gdy nadal jesteśmy świadkami epoki podzielonych, partykularnych zbiorowości pozostających względem siebie ciągle w gotowości bojowej. Ideologia neoliberalna chce prezentować się jako służka globalnego procesu zjednoczenia się całego świata, a jest jedynie wyrazem radykalnej chciwości ludzkiego gatunku i zasłaniania bielmem racjonalnej dyskusji i filantropii bogatych problemy głodujących mas trzeciego świata. Solidarność na poziomie światowym nadal pozostaje pustym słowem, a demokracja ludzkości jest raczej kpiną neoliberalnego burżuja niż realną możliwością w obliczu trosk przeciętnego człowieka. Jak trafnie wskazuje Peter Sloterdijk: „Aktualna sytuacja świata odznacza się tym, że nie posiada on żadnej efektywnej struktury ko-immunizacyjnej dla członków „światowego społeczeństwa”. Na najwyższym poziomie solidarność jest jeszcze pustym słowem. Nadal trafne w odniesieniu do niej jest dictum kontrowersyjnego konstytucjonalisty: „Kto mówi $<<l u d z k o s ́ c ́>>$, ten chce oszukiwać”. Powód leży jak na dłoni: efektywne ko-immunizujące jednostki solidarnościowe sa dzisiaj, tak jak $i w$ dawnych czasach, sformatowane rodzinnie, plemiennie, narodowo i imperialnie, ostatnio także $w$ regionalnych sojuszach strategicznych, i funkcjonuja - o ile w ogóle funkcjonuja - adekwatnie do zmiennych formatów różnicowania własne-obce. Dlatego póki co skuteczne sojusze przetrwania sa partykularne - także „religie światowe”, zgodnie z natura rzeczy, nie moga być niczym więcej jak tylko prowincjonalizmami na wielka skalę. (...) Ludzkość nie tworzy superorganizmu - jak twierdza pochopnie niektórzy teoretycy systemów - jest ona na razie tylko agregatem „organizmów” wyższego rzędu, które w żadnym wypadku nie sa jeszcze zintegrowane w sprawna operacyjnie jednostkę najwyższego uporządkowania"29.

W obliczu nowoczesnych manipulacji informacją w celu zawiadywania szerokimi masami społeczeństwa coraz ciężej myśleć o możliwości przeciwstawienia się władzy partyjnych celebrytów, nawet wtedy, gdy ewidentnie wykonują działania przeciwne interesom całego społeczeństwa. Niestety nadal jedyną opcją pozostają walki uliczne i realna groźba użycia przemocy fizycznej, ponieważ w obliczu formalnej przewagi legitymizującego

${ }^{29}$ P. Sloterdijk, Musisz życie swe odmienić, przeł. J. Janiszewski, PWN, Warszawa 2014, s. 627. 
działania prawa, pozostającego w rękach liberalnych oprawców, społeczeństwo może odwołać się jedynie do pierwotnego uczucia strachu rządzących nim tyranów, połączonego z wyraźnie wyartykułowanymi postulatami zmian. Trzeba wreszcie uświadomienia tego, że polityka nigdy nie jest działaniem w zgodzie. Warunkiem istnienia polityki jest ontologiczny wymiar antagonizmu zwany przez Schmitta politycznością, dzięki czemu staje się ona w ogóle możliwa. Walka między konkurencyjnymi projektami hegemonicznymi nigdy się nie kończy. Każdy z nich chce mieć wyłączność na prawdziwość. Wszelka krytyka polityczna jest walką z jakimś aspektem istniejącej hegemonii, nie ma czegoś takiego jak obiektywna, intersubiektywna polityka. Jak znakomicie oddaje to Mouffe: „Myślenie o polityce jako „działaniu w zgodzie” prowadzi do eliminowania ontologicznego wymiaru antagonizmu, nazywanego przeze mnie „politycznością", który zapewnia polityce jej quasi-transcendentalny warunek możliwości. Zawsze będzie trwała walka między skonfliktowanymi projektami hegemonicznymi usitującymi przedstawić swoje poglady na dobro wspólne jako "prawdziwe" wcielenie uniwersalności. I nie będzie możliwe żadne racjonalne rozwiązanie tego konfliktu. Jeśli chodzi o krytykę polityczną, nigdy nie może być ona tylko opozycyjna ani pojmowana jako ucieczka, bo zawsze gra z jakimś aspektem istniejącej hegemonii, aby dezartykułować/reartykułować jej konstytutywne elementy"30.

Twierdzenie wielu partyjnych watażków jakoby odkrywali przed nami rzeczywistość prawdziwą, niezmąconą ich ideologicznym usytuowaniem jest zwykłą hipokryzją. Polityka zawsze polega na splataniu się uniwersalności z partykularnością i każda z nich musi znaleźć swój w niej wydźwięk. Antagonizmy wewnętrze powinny być twórczo transformowane w agonizmy, czyli kontrpropozycje składane na forum publicznym przez przeciwników lecz nie wrogów. Jednak, kiedy widzimy to, że w rzeczywistości demokracja i liberalizm nie są złączone ze sobą na trwałe i na co wiele wskazuje ich nieuchronny rozpad następuje, to spojrzenie Mouffe na polityczność też powinno być zrewidowane, gdyż niedługo może nastąpić próba nie tyle realtykulacji istniejących stosunków w nowej konfiguracji hegemonicznej, co zmienienie całej formuły i logiki przestrzeni politycznej, ustanowienie nowego ustroju. Pozbawienie polityki sfery nierówności i sprowadzenie jej do obszaru jednorodnej i pozbawionej różnic powoduje, że staje się ona odarta z treści i formy, a jej znaczenie zanika przechodząc na inne rejony życia - takie jak np. ekonomia. ${ }^{31}$ Polityczność nie może abstrahować od problematyki różnic, która jest dla niej konstytutywna

\footnotetext{
${ }^{30}$ Ch. Mouffe, Agonistyka. Polityczne..., dz. cyt., s. 86-87.

${ }^{31}$ C. Schmitt, Duchowa i historyczna sytuacja dzisiejszego parlamentaryzmu, [w:] Teologia polityczna i inne pisma, przeł. M.A. Cichocki, Wydawnictwo Aletheia, Warszawa 2012, s. 155.
} 
ponieważ, gdy tylko zaczyna głosić abstrakcyjną, moralistyczną liberalną ideę powszechnej równości, to traci swoją istotę, stając się nic nieznaczącym obszarem życia społecznego. Cała treść sfery publicznej i demokracji wynika ze znaczenia i problematyki różnicy wobec ludzi. Głoszenie powszechnej równości osłabia i niweluje znaczenie i wartość politycznej identyczności jednostek wchodzących w obszar demokratycznego państwa. Substancjalne nierówności są konstytutywne dla znaczenia polityki i jeśli się je przestanie dostrzegać ich dynamiczna i nieokiełznana natura da o sobie znać w innych formach ludzkiej aktywności, które przejmą i zdominują obszar wyjałowionej ze znaczenia polityczności. ${ }^{32}$

\section{Kryzys systemu kapitalistycznego i konieczność powrotu do myśli krytycznej wobec obowiązującego reżimu akumulacji w celu przezwyciężenia dominacji tradycji liberalnej}

W dzisiejszych czasach mamy niewątpliwe do czynienia z kryzysem demokracji, często również utożsamiamy ją z tzw. zachodnioeuropejskim podejściem do życia i jego wartościami. Wynika to po części z tego, że w sposób nieświadomy łączymy w sposób nierozerwalny kapitalizm z demokracją jako dwa oblicza tego samego ustroju. Jednak tak nie jest. Właśnie, jak to się w toku dalszego wywodu wyjaśni, kryzys jednego jest powiązany z drugim i na odwrót. Otóż te dwa elementy mogły pozostawać czas jakiś w połączeniu, ale teraz konieczne jest ich rozdzielenie, co w sposób wizjonerski spostrzegł już Schmitt: „Kryzys demokracji prowadzi $w$ dalszej konsekwencji do kryzysu parlamentaryzmu, którego jednak nie należy mylić z kryzysem demokracji. Oba zjawiska występują dzisiaj jednocześnie, wzajemnie się potęujac. W rzeczywistości sa jednak pojęciowo zupelnie różne. Demokracja masowa jako demokracja dąży do osiagnięcia identyczności rządzących i rządzonych, a da$\dot{z} a c$ do tego, napotyka na swej drodze parlament jako instytucje już niezrozumiała i przestarzała. Jeżeli poważnie potraktujemy demokratyczny postulat identyczności, to w konkretnej sytuacji podejmowania decyzji nie może być żadnej innej miarodajnej instytucji poza wyra$\dot{z}$ ona jakoś $w$ danym momencie nieodwołalna wola ludu. W demokracji masowej nie da się uzasadnić istnienia instytucji, której istota polega na dyskusji niezależnych przedstawicieli. Tym bardziej, że wiara $w$ dyskusje ma liberalne, a nie demokratyczne korzenie" ${ }^{\prime 3}$.

Te wnikliwe spostrzeżenie potwierdzają dzisiejsze czasy, w których Chiny pretendujące do roli światowego mocarstwa w sposób niezwykle wprost owocny łączą kapitalizm z brutalnym reżimem partii komunistycznej. Sprawa nie wygląda tak, że gdyby Chińczy-

\footnotetext{
32 Tamże, s. 155-157.

33 Tamże, s. 158.
} 
cy wprowadzili demokrację, to ich postęp gospodarczy postępowałby jeszcze szybciej. To właśnie dzięki tzw. reżimowi komunistycznemu jesteśmy świadkami tak nieprawdopodobnego wzrostu gospodarczego nowego światowego mocarstwa. Pamiętajmy, że na początku rozwoju kapitalizmu koegzystował on w Europie z bezwzględnymi reżimami władzy, które wcale nie były łagodniejsze od dzisiejszych Chin: „Zamiast patrzeć na współczesne Chiny jako wschodnie, despotyczne wypaczenie kapitalizmu, spójrzmy na nie raczej jako na powtórkę z rozwoju kapitalistycznej Europy. U zarania nowożytności państwom europejskim daleko było do demokracji, a jeśli już demokracja pojawiała się w jakimś kraju (np. w Holandii), to dotyczyła jedynie liberalnych elit, a nigdy robotników. Warunki kapitalizmu zostały stworzone, a potem były podtrzymywane przez brutalna dyktature, bardzo podobna do tej panującej dziś w Chinach - państwo legalizowało brutalne wywłaszczanie zwykłych ludzi, zamieniało ich $w$ proletariuszy i tresowało ich do tej nowej roli. Wszystko, co dziś wiążemy $z$ liberalna demokracja $i z$ wolnościa (związki zawodowe, powszechne wybory, darmowa, publiczna edukacja, wolność prasy, itd.) nie jest $w$ żadnym razie „naturalna” konsekwencja stosunków kapitalistycznych, lecz zostało z wielkim trudem i poświęceniem wywalczone przez niższe klasy w XIX w. Przypomnijmy sobie listę żadań zawartych w Manifeście Komunistycznym - wszystkie one, wyjąwszy zniesienie prywatnej własności środków produkcji, zostały wprowadzone $w$ „,burżuazyjnych” demokracjach. Lud to sobie wywalczyl”34.

ZSRR wybrało więc prawdopodobnie najgorszą drogę z możliwych wprowadzając od razu demokrację razem z kapitalizmem, jako lekarstwo na wszystkie swoje problemy. Był to niewątpliwie ogromny błąd, ponieważ jeśli Rosja wdrożyłaby jedynie kapitalizm łącząc go z komunistycznym centralnym zarządzaniem i autorytaryzmem prawdopodobnie w tej chwili ona, a nie USA byłaby światowym hegemonem. W tym przypadku brak partii sprawującej mocną kontrolę polityczną i interweniującą w razie jakiejkolwiek potrzeby był katastrofalnym błędem. Zamknęło to Rosji drogę do stania się realną światową alternatywą dla USA, a Chiny stały się jedynym prawdziwym konkurentem Stanów Zjednoczonych na arenie światowej. ${ }^{35}$ Niewątpliwie taka droga rozwoju byłaby o wiele korzystniejsza również

${ }^{34}$ S. Žižek, Między demokracją a boską przemoca, [w:] Co dalej z demokracją?, red. P. Wielgosz, przeł. M. Kowalska, Instytut Wydawniczy Książka i Prasa, Warszawa 2012, s. 139.

${ }^{35}$ Tamże, s. 142., „Czy istnieje lepszy argument na korzyść chińskiej drogi do kapitalizmu, a przeciw rosyjskiej? Po upadku komunizmu Rosja zafundowała sobie „terapię szokową” - natychmiastowe przejście do demokracji plus ekspresowe wdrożenie kapitalizmu. Skutkiem była gospodarcza katastrofa. Chińczycy przeciwnie, naśladując Chile i Południową Koreę, bez skrupułów używają autorytarnej władzy państwa do kontrolowania społecznych kosztów przechodzenia do kapitalizmu i to pozwala im uniknąć chaosu. Okazuje się więc, że dziwaczne na pozór połączenie kapitalizmu z komunizmem jest nie tyle absurdalną anomalią, ile nie do końca zamaskowanym 
dla Polski, która mogła przecież wprowadzić kapitalizm nie rezygnując (jedynie przez jakiś okres przejściowy) z centralnej roli partii komunistycznej i jej politycznej i ekonomicznej kontroli nad wolnym rynkiem. Dzięki temu bylibyśmy teraz być może Chinami Europy, a nie zajmowalibyśmy peryferyjną pozycję w Unii Europejskiej.

Tak więc twierdzenie, że demokracja musi pozostawać w związku z neoliberalizmem i nie może spróbować mariażu z innym podejściem, takim chociażby jak zmodyfikowany marksizm, albo nawet przemodelowany, transformowany w nowy twór komunizm mija się z celem. Według Mouffe Schmitt popełnia błąd, kiedy rozumie lud w sposób esencjonalistyczny. Twierdzi ona, że lud jest również społecznie tworzonym konstruktem i nie da się go sztucznie wyabstrahować. Tożsamość zbiorowa określana jako lud jest obiektem hegemonicznych działań, procesów artykulacji i nie można tworzyć z ludu abstrakcyjnego podmiotu rządzenia, który jest oddzielony od procesu jego definiowania i konstruowania. ${ }^{36}$ Niemniej jednak lud musi pozostać podstawowym pojęciem dla praktyki demokratycznej. To prawda, że proces konstruowania tożsamości zbiorowych powstaje w relacji konstytutywnego wykluczenia bez którego nie mogłaby zaistnieć polityczność. Paradoksem tutaj jest to, że aby mogła zaistnieć równość musi również powstać pewna forma alienacji, wykluczenia. Głównym problemem wprowadzanym na arenę demokratycznej walki jednych przeciwko drugim jest liberalne pojęcie ludzkości. Postulowanie owego abstrakcyjnego konstruktu, który niweluje element wyobcowania i wprowadza fałszywe pojmowanie uniwersalności, skutkuje niezrozumieniem natury podejmowanych działań. Jest to błędne rozumienie polityczności. ${ }^{37} \mathrm{~W}$ dzisiejszych czasach nieuniknione staje się sięgnięcie do idei komunistycznej, w której postulaty równości, wolności i braterstwa nie są jedynie odległymi i nierealnymi ideami ale czymś, o co realnie trzeba zabiegać i o co można się upominać. Jak pisze francuski filozof Alain Badiou: „Jeśli za przeciwieństwo jakiejś doktryny uważamy nie jej karykaturalne odwrócenie, ale twórcze twierdzenie obalajace w proch cała jej maszynerię, wówczas zobaczymy, że odwrotnością demokracji - takiej, jak ja rozumie, w momencie jej nieustajacego schyłku, system kapitalistyczno-parlamentarny - nie

dobrodziejstwem. Błyskawiczny rozwój Chin dokonuje się nie mimo komunistycznego rządu, lecz dzięki niemu. Zakończmy ten wątek sugestią o lekko stalinowskim wydźwięku, że być może tym, którzy martwią się brakiem demokracji w Chinach, tak naprawdę przeszkadza szybki rozwój tego kraju, czyniący z niego supermocarstwo zagrażające zachodniej dominacji?” Demokracja nie jest więc koniecznym partnerem dla kapitalizmu.

${ }^{36}$ Ch. Mouffe, Carl Schmitt i paradoks demokracji liberalnej, [w:] Carl Schmitt. Wyzwanie polityczności, red. Ch. Mouffe, Wydawnictwo Krytyki Politycznej, Warszawa 2011, s. 67.

${ }^{37}$ Tamże, s. 57. 
jest ani totalitaryzm, ani dyktatura, lecz komunizm. Komunizm - ujmując rzecz po heglowsku - wchlania i przezwycięża ograniczony formalizm demokracji”38.

Komunizm, choć w wersji stalinowskiej i leninowskiej popełniał koszmarne czyny, był jednak wtedy wypaczoną wersją samego siebie, co nie zmienia tego, że zawierał w sobie pewną uniwersalną prawdę (w odróżnieniu np. od nazizmu) będącą przeciwstawną wobec kapitalizmu. ${ }^{39} \mathrm{~W}$ dzisiejszych czasach jest już oczywiste, że nie możemy zaprzepaścić spadku marksizmu, ponieważ jest to tradycja, która oferuje alternatywne myślenie o kapitalizmie i ma w sobie wciąż siłę zdolną doprowadzić do przemiany obecnego systemu, który w dalszej kontynuacji układu z neoliberalizmem doprowadzi do światowej wojny, albo powszechnego niewolnictwa. Jeśli byśmy dzisiaj w taki sam sposób w jaki odrzucamy komunizm nie uznawali Kościoła Katolickiego byłoby to dla mnie przynajmniej konsekwentne podejście. W obliczu wielkiej ilości zbrodni, krucjat, inkwizycji, masowych mordów religijnych, m. in. rzezi hugenotów we Francji, palenia książek, które są teraz podstawą naszej kultury i późniejszej kolaboracji z faszystami ${ }^{40}$ również można by było obstawać za takim rozwiązaniem. Komunizm nie został zdyskredytowany, twierdzić, że stalinizm i leninizm były dziełem pism Karola Marksa, to tak jak uznawać, że Ewangelia i zawarte w niej nauczanie Jezusa Chrystusa było wykładnią wszystkich brutalnych czynów dokonywanych na przestrzeni stuleci przez instytucję Kościoła Katolickiego. Konstatację więc jakoby idea komunizmu była skompromitowana uważam za bezzasadną. Tak samo jak za nieuprawnione uważam przyrównywanie karygodnych czynów popełnionych w imieniu chrześcijaństwa do nauki Jezusa. Na pewno nie był on odpowiedzialny za przekręty w Banku Ambrozjano.

Niezwykle istotne, szczególnie dla nas dzisiaj jest spojrzenie schmittowskie na demokrację, jak i na liberalizm. Być może bowiem tam kryje się rozwiązanie interesujących nas problemów, w obliczu których stajemy w dzisiejszej rzeczywistości politycznej. Co się stanie, jeśli znowu staniemy przed spektaklem najgorszych wynaturzeń, na jakie jest gotowa ludzka natura, aby wyprzeć ryzyko najazdu Innego na Europę? Czy aby problem imigrantów/uchodźców i narastające napięcie międzynarodowe są efektem nie tyle działań jednostkowych, co rezultatem wad i sprzeczności samego neoliberalizmu? Czy być może

\footnotetext{
${ }^{38}$ A. Badiou, Demokracja jako emblemat, [w:] Co dalej z demokracją?, red. P. Wielgosz, przeł. M. Kowalska, Instytut Wydawniczy Książka i Prasa, Warszawa 2012, s. 26.

${ }^{39}$ Zob. A. Badiou, Etyka, Wydawnictwo Krytyki Politycznej, Warszawa 2009, przedstawienie przez Badiou nazizmu jako systemu politycznego posługującego się pozorem prawdy na s. 86-90.

${ }^{40}$ Zob. M. Agnosiewicz, Kościół a faszyzm. Anatomia kolaboracji, Wydawnictwo racjonalista.pl, Wrocław 2009.
} 
nie powinniśmy zmienić samego systemu reprodukującemu nieuniknione zło, zamiast zaklinać, żeby nie nadeszło najgorsze z ludzkich wcieleń, jakim jest wojna totalna, skierowana na wyniszczenie przeciwnika? Już tych kilka pytań uświadamia nam skalę problemów przed jakimi stoimy jako finalna generacja kapitalistycznego molocha. W całej Europie potępia się holocaust i straszne zdarzenia z nim związane, ale już nie dostrzega się tego, że w powietrzu ciągle wisi, tli się możliwość powtórki. Może i jednoznacznie potępiono Auschwitz ale jego idea proszę mi wierzyć krąży nad Europą i domaga się ponownego wcielenia jej w życie. Zauważmy tutaj, że sam holocaust nie był pierwszym ludobójstwem na ogromną skalę. Wystarczy tutaj wspomnieć króla Leopolda II i jego dzieło czyli wymordowanie około 10 milionów mieszkańców Konga Belgijskiego. ${ }^{41}$ Nigdy nie został on jednoznacznie potępiony na forum światowym. Wydaje mi się, że i dzisiaj szykuje się niestety powtórka z rozgrywki. Czy czeka na kolejna wielka rzeź, tym razem imigrantów? Czy globalny kapitalizm znowu nabierze rozpędu dzięki przemysłowi zbrojeniowemu? Mam nadzieję, że nie.

Pożądana homogeniczność mieszkańców europejskich państw narodowych i brak solidarności europejskiej oraz rosnące poparcie dla ruchów neofaszystowskich może się okazać czarnym końcem tolerancji europejskiej, jej nawracającym Innym, który choć wykluczony jest skrycie hołubiony, domaga się uwagi. Smutną rzeczywistością z którą mamy do czynienia jest nie tylko rozpad starego małżeństwa liberalizmu i demokracji, ale i powolny schyłek tejże ostatniej. Okazuje się, że i w samym jądrze demokratycznej praktyki czają się sprzeczności, które bez właściwej analizy i przepracowania przyczyniają się do jej rozpadu. Jak pisze Schmitt: „Wydaje się więc, że demokracja nieuchronnie unieważnia samą siebie za sprawa sprzeczności wynikających ze sposobu, w jaki kształtuje się wola ogótu. Dla radykałów demokracja sama w sobie ma wartość bez względu na treść polityki realizowanej za jej pomoca. Jednak $w$ obliczu realnego niebezpieczeństwa użycia demokracji do zburzenia ustroju demokratycznego radykalny demokrata staje wobec konieczności dokonania wyboru: albo wystąpi przeciwko większości w obronie demokracji, albo poświęci demokrację zgodnie z wola ogółu. Jeżeli utożsamiamy demokrację z jakąś treścią, która sama w sobie ma dla nas pewna wartość, to ( $w$ sensie formalnym) nie możemy już pozostawać demokratami za wszelką cenę. Ta, przyznać trzeba, zaskakująca konieczność wynika z samej idei demokra-

\footnotetext{
${ }^{41}$ A. Hochschild, Duch króla Leopolda. Opowieść o chciwości, terrorze i bohaterstwie w kolonialnej Afryce, przeł. P. Tarczyński, Wydawnictwo Weltbild/Świat Książki, Warszawa 2012. Dokładna liczba nie jest nawet znana. To dosyć jednoznaczne, że holocaust został tak bezwzględnie wyklęty, a ludobójstwo Afrykanów już niewielu raczyło zauważyć. Od razu widać, kto jest tutaj dominującą hegemonią.
} 
cji, nie jest wytworem jakiejś abstrakcyjnej, sofistycznej spekulacji, lecz faktem. Demokraci często przecież znajduja się w mniejszości. Taka sytuacja wcale nie jest wyjątkowa. Zdarza się również, że w imię, jak sądza, demokracji opowiadaja się za przyznaniem kobietom praw wyborczych, po czym ze zdziwieniem stwierdzają, że większość z nich wcale nie głosowała za demokracja"

Rola większości jako woli ludu w demokracji jest bardzo problematyczna, szczególnie, gdy społeczeństwo prezentuje niski poziom jakości intelektualnej i moralnej. Może to doprowadzić do uchwalania absurdalnych praw tylko dlatego, bo tego wymaga ustrój. W konsekwencji prowadzić do tyranii zdania ogółu nad jednostką, zamykając jej drogę do wyrażenia swojego zdania, a w ekstremalnych przypadkach eliminując ją. Również NSDAP partia, która wyniosła Hitlera do władzy zrobiła to w mniej lub bardziej demokratyczny sposób. Pojawiają się pytania: czy jeśli partia, która wygrywa w sposób właściwy, ale ewidentnie nie szanująca konstytucji danego kraju i praw opozycji, mniejszości nie powinna zostać zdelegalizowana, gdy łamie prawa państwa i jego obywateli? Czy np. w świetle ostatnich wydarzeń w Polsce można wysuwać roszczenia odsunięcia od władzy obozu rządzącego jako nie przestrzegającego reguł na mocy których został wybrany i działającego według niektórych na szkodę własnych obywateli? Czy też jego postępowanie daje się wytłumaczyć (jest prawomocne) jako legitymizowane wolą większości. Raport Komisji Weneckiej ${ }^{43}$ nasuwa podejrzenia, że łamane są konstytucyjne prawa obywateli (jednak jest to instytucja zewnętrzna wobec narodu Polskiego) - czy wobec tego żyjemy jeszcze w demokracji?, a może tak naprawdę jest ona od początku fasadą dla neoliberalnego kapitalizmu.

Tak więc bez dogłębnego przeformułowania demokratycznej praktyki i teorii, skorzystania $\mathrm{z}$ intelektualnego dorobku marksizmu i postmarksizmu ${ }^{44}$ nie ma mowy o wypracowaniu realnej alternatywy dla kapitalizmu, który powoli pożera znany nam świat i spycha go w czeluści kolejnej światowej wojny. Sama rewolucja już nie wystarczy, nie chodzi o to, żeby bezmyślnie wprowadzać stare rozwiązania, ale żeby skonstruować nowe, nie będące jedynie zmianami konsumentów przywilejów władzy neoliberalnej hegemonii, powielaniem istniejących układów między politycznymi i finansowymi elitami. Należy

\footnotetext{
${ }^{42}$ C. Schmitt, Duchowa i historyczna sytuacja dzisiejszego parlamentaryzmu, [w:] Teologia polityczna i inne pisma, przeł. M.A. Cichocki, Wydawnictwo Aletheia, Warszawa 2012, s. 171.

43 Raport Komisji Weneckiej w całości, część I: http://www.tvn24.pl/wiadomosci-z-kraju,3/przeczytaj-cala -opinie-komisji-weneckiej,626862.html (dostęp 08.04.2017). Część II: http://www.tvn24.pl/wiadomosci-z-kra ju,3/przeczytaj-cala-opinie-komisji-weneckiej-czesc-2,626871.html (dostęp 08.04.2017).

${ }^{44}$ Zob. S. Tormey, J. Townshend, Od teorii krytycznej do postmarksizmu, PWN, Warszawa 2010.
} 
w końcu znaleźć jakieś choćby częściowe rozwiązanie dla tych od wieków ścierających się bestii: „Fakt, iż to właśnie Lewiatan oznacza państwo, a Behemot rewolucję, nie wynika rzecz jasna z jakichś spekulacji Hobbesa nad mitami. Nie jest wszak przypadkiem, że dla siedemnastowiecznych Anglików zwierzę wodne staje się symbolem porządku gwarantującego pokój - Lewiatan, „olbrzymi wieloryb”, narzucat się wyobraźni narodu angielskiego. W istocie jednak obie formy, zarówno wymuszający pokój porzadek państwowy, jak i rewolucyjna, anarchiczna siła stanu natury, w równej mierze korzystaja we wzajemnej walce z elementarnej przemocy. Zdaniem Hobbesa państwo to jedynie odwlekana bez przerwy dzięki potężnej władzy wojna domowa. Innymi słowy: jeden potwór, Lewiatan albo "państwo", nieustannie powstrzymuje drugiego potwora, Behemota "rewolucji"'45.

Trzeba wynaleźć nowy sposób, aby sprzęgnąć te siły w działaniu przeciwko wspólnemu wrogowi, jakim jest teraz globalny kapitalizm i wypracować realną, prowadzącą do lepszego świata nie opartego na ciągłym wyzysku jednych przez drugich alternatywę. Przykład Haiti jest dowodem na to, jak nawet najwspanialsze idee zostają zgniecione przez kapitalistyczny system globalnej finansjery. Pomimo z trudem wywalczonej wolności od białych ciemiężycieli podczas rewolucji haitańskiej (14 sierpnia 1791 - 1 stycznia 1804). Mieszkańcy zostali za to przykładnie ukarani przez globalną finansjerę i musieli w upokarzający sposób spłacać się Francji za własne wyzwolenie. Do dzisiaj uiszczają oni kapitalistycznym mocarstwom opłatę za koszty swojej walki o wolność i równość jaką jest życie w nędzy i ubóstwie. Taką cenę płaci dumna ludność pierwszej „czarnej” republiki za sprzeciwienie się kapitalistycznym oprawcom: „Dowodzona przez Toussainta Louverture’a rewolucja haitańska naprawdę zasługuje na to, by nazwać ja powtórka z Rewolucji Francuskiej. Można o niej powiedzieć, że „wyprzedzała swoje czasy”, że była „przedwczesna”, skazana na porażkę i właśnie dlatego uznać ja za wydarzenie może nawet bardziej niezwykłe niż sama Rewolucja Francuska. Po raz pierwszy bunt skolonizowanego ludu nie miał na celu powrotu do przedkolonialnych „korzeni”, lecz dokonat się w imię bardzo nowoczesnych idei wolności i równości. Jakobini natychmiast poparli powstanie niewolników, co w pewnym sensie dowodzi autentyczności ich zaangażowania. Czarna delegacja z Haiti została przez Konwent Narodowy przyjęta z entuzjazmem. Jak można się było spodziewać, wszystko zmieniło się po Thermidorze - Napoleon czym prędzej wysłał swoja armię, by ponownie zajęła Haiti. (...) Trzeba było więc uczynić z Haiti modelowy przykład gospodarczej porażki, by zniechęcić inne kraje do pójścia w jego ślady. Cena - $w$ dosłownym ekonomicznym, sensie - tej „przedwcze-

${ }^{45}$ C. Schmitt, Lewiatan $w$ teorii państwa Thomasa Hobbesa, przeł. M. Falkowski, Prószyński I S-ka, Warszawa 2008 , s. 31-32. 
śnie" uzyskanej niepodległości okazała się astronomiczna. Francja, której Haiti było kolonia dopiero po 20 latach embarga, $w 1825$ r., nawiazala $z$ nim stosunki handlowe $i$ dyplomatyczne, a Haiti musiało zgodzić się na zapłacenie $150 \mathrm{mln}$ franków „rekompensaty” za utratę niewolników. Suma ta, stanowiąca mniej więcej ówczesny roczny budżet Francji, została później zmniejszona do $90 \mathrm{mln}$, ale nadal było to gigantyczne obciążenie, uniemożliwiające wzrost gospodarczy. Pod koniec XIX w. wpłaty dla Francji stanowiły około 80\% budżetu kraju. Ostatnia rata została zapłacona w 1947 r." ${ }^{36}$. Kiedy haitański prezydent Jean-Bertrand Aristide w 2004 zażądał spłaty wymuszonego długu jego żądanie zostało zlekceważone nawet przez lewicowe środowiska, a on sam przy wsparciu Francji i USA obalony, po dziś dzień około 80\% Haitańczyków żyje w skrajnej biedzie, a ich państwo należy do najuboższych na świecie. To jest prawdziwe oblicze kapitalizmu dla tych, którzy ukochali wolność i równość, byli gotowi za nie walczyć i umierać. Do dzisiaj ci waleczni ludzie cierpią z głodu za to, że ważyli się upomnieć o swoje. ${ }^{47}$

Życie w świecie napędzanym zyskiem nie może być rozwiązaniem, a sam liberalizm, wprowadzający na miejsce świętości własność prywatną musi zostać obalony. W dzisiejszym społeczeństwie liberalnym uznawane jest pierwszeństwo prawa prywatnego i chroni się przede wszystkim własność prywatną. Skąd jednak owa zasada zbiera w sobie taką przedziwną i prawie, że sakralną moc, że jakiekolwiek wystąpienie przeciwko niej, jest ogłaszane jako bunt przeciwko społeczeństwu, a sprawcę tego wykroczenia karze się jak najsurowiej. Dlaczego wystąpienie przeciwko własności prywatnej jest czymś niemalże gorszym od aktu terrorystycznego? Formę prawną sprowadza się w dużej mierze do obrony tego pojęcia i dominuje ono w ekonomii. Oczekuje się w tym systemie, że życie społeczne będzie rządzić się samo z siebie. Jednakże tak naprawdę wszystko staje się kwestią osobistą, a demokratyczna idea reprezentacji po prostu nie istnieje. Nawet opinia publiczna jest kształtowana przez media, które pozostają przede wszystkim w rękach władzy prywatnej. Zjawisko sprywatyzowania bierze swój dziejowy początek od religii. Wolność wyznania była pierwszym poważnym prawem indywidualnym. Później w miarę rozwoju społeczeństw dołączały kolejne prawa takie jak wolność sumienia, mediów, handlu, itp. Co

${ }^{46}$ S. Žižek, Między demokracją a boską przemocą, [w:] Co dalej z demokracją?, red. P. Wielgosz, przeł. M. Kowalska, Instytut Wydawniczy Książka i Prasa, Warszawa 2012, s. 145-146. O czym trzeba wspomnieć część Polskich żołnierzy wysłanych przez Napoleona do pacyfikacji rewolucji stanęła po stronie walki o wolność przeciwko Francuzom, nie mogąc walczyć przeciwko tym, którzy tak jak oni chcieli wyswobodzenia swej ojczyzny. W pierwszej haitańskiej konstytucji było zakazane osiedlanie i posiadanie ziemi jakimkolwiek białym ludziom. Zapis ten jednak nie dotyczył Polaków.

47 Tamże, s. 146-147. 
ważne jednak religia w dowolnym umiejscowieniu kulturowym zawsze zachowuje potężną absolutyzującą i pociągającą siłę. To niezwykle istotne ponieważ wraz z tym, że religia, wyznanie staje się sprawą osobistą następuje uświęcenie tejże sfery, uczynienie jej obszarem sakralnym, nieoddzielnym od jego religijnego pierwowzoru. Paradoksalnie własność prywatna dlatego leży w obszarze sacrum, ponieważ uznaje się ją za sprawę osobistą. Bez owej domeny cały gmach współczesnego, liberalnego społeczeństwa rozpadłby się. Tam, gdzie istnieje święte, nienaruszalne prawo absolutnej indywidualnej własności, tam też religia jest sprawą prywatną: „Oczekuje się, że życie społeczne - opanowane przez opinię publiczna, wyrażane przez jego uczestników, a więc przez prywatne osoby - będzie rządzito się samo. Z kolei opinię publiczna kształtuje przede wszystkim prasa pozostajaca w prywatnych rękach. Nic w tym systemie nie jest kwestia reprezentacji, natomiast wszystko jest sprawa prywatna. $Z$ historycznego punktu widzenia zjawisko sprywatyzowania rozpoczęło się u samych podstaw - od religii. Pierwszym prawem indywidualnym w sensie mieszczańskiego porządku społecznego była bowiem wolność wyznania. Stanowi ona początek i jednocześnie zasadę historycznego rozwoju katalogu takich praw, jak wolność wyznania i sumienia, wolność zrzeszania się i gromadzenia, wolność prasy, wolność handlu i rzemiosła. Religia, ujęta $w$ dowolnym kontekście, zawsze zachowuje swoja absorbujaca i absolutyzujaca moc. Jeżeli więc religijność ma być kwestia prywatna, to również odwrotnie: prywatność zostaje religijnie uświęcona. Obie sfery nie daja się już od siebie oddzielić. Własność prywatna jest dlatego święta, że uważa się ja za sferę prywatną. Ten dotąd słabo rozpoznawany związek wyjaśnia socjologiczne znaczenie rozwoju współczesnego społeczeństwa europejskiego. Również współczesne społeczeństwo zostało religijnie uświęcone przez sferę prywatną: bez niej gmach porzadku społecznego zawaliłby się. Fakt, że religia jest kwestia prywatna, nadaje prywatności sankcję religijną. Co więcej, wolna od wszelkiego ryzyka gwarancja absolutnej własności prywatnej istnieje we właściwym sensie jedynie tam, gdzie religia jest sprawa prywatna" ${ }^{\prime \prime}$.

Główną zasadą panującego porządku nie może być bowiem nie znająca granic akumulacja kapitału i wykorzystywanie coraz bardziej bezradnych mas manipulowanych za pomocą przysługujących im jakoby wolności. Narastające stosunki nowego feudalizmu domagają się zmiany, nie może być tak, że w świetle uzasadniającego wszystko formalizmu prawa małe dzieci giną z głodu, dorośli żyją w skrajnej nędzy, a neoliberalna propaganda sukcesu wychwala tych, którzy znaleźli sobie miejsce w szeregach panującej hegemonii.

\footnotetext{
${ }^{48}$ C. Schmitt, Rzymski katolicyzm i polityczna forma, [w:] Teologia polityczna i inne pisma, przeł. M.A. Cichocki, Wydawnictwo Aletheia, Warszawa 2012, s. 129-130.
} 
Uświęcona konsumeryzmem kapitalistyczna prawda nieustającej rywalizacji nie może być remedium dla ogółu, bo nie potrafi wyżywić głodujących mas trzeciego świata. Nie zna owa neoliberalna religia strachu przed rozpętywaniem światowych wojen w imię zysku, a wszelkie żądania żyjących w nędzy, lub na jej skraju podatników, będących podstawą ich finansowej góry traktuje jak żądania żałosnej bandy nieudaczników. Jest to niedopuszczalne, ten system domaga się zmian i ludzie, a nikt inny mają prawo je wprowadzić. Pracownicy, którzy drżą ze strachu przed decyzją pracodawcy, która może doprowadzić do utraty domu i wyżywienia ich z trudem wiążące koniec z końcem rodziny - oto jest świat kapitalistycznego dobrobytu nielicznych kosztem licznych, to jest wolność i równość oraz braterstwo, które proponuje biednym i cierpiącym tego globu neoliberalna religia. Finansiści i zbierające okrawki z pańskiego stołu intelektualne elity wcale nie są w większości zainteresowane wprowadzeniem zmian, bo w rzeczy samej nie obchodzi ich to, że żyją kosztem innych. Największe na świecie imperium to społeczeństwo, które posługując się rasistowskim i dyskryminującym Afroamerykanów językiem, ponownie doprowadza do skrajnego zubożenia i nędzoty tych, którzy z takim trudem wywalczyli sobie zniesienie apartheidu ${ }^{49}$. Najgorsze jest to, że cała ta tragiczna sytuacja jeszcze wcale nie osiągnęła apogeum. Nierówności ciągle się powiększają, a siły rynkowe łamią życia i nadzieję coraz większej ilości ludu pracującego. Słusznie pisze Peter McLaren: „System finansowy stuży nie tylko utrzymywaniu przepaści między bogatymi a biednymi, lecz także jej powiększeniu. Nie możemy się cofnąć - nie jesteśmy w stanie odwrócić neoliberalnej globalizacji. Możemy jednak uciec do przodu, pójść w kierunku socjalistycznej alternatywy i podbić nowy świat. Ekstensywny i intensywny wzrost kapitału, rozmywanie się granic między kapitałem a państwem, zdominowanie państw rozwijających się przez państwa rozwinięte, dokonujące się za pomocą brutalnych sił rynkowych oraz zintegrowanych procesów kapitalistycznej produkcji (czyli wykorzystywania taniej sity roboczej i zarzadzania surowcami), pozbawianie chłopów ziemi, hegemonia dolara jako waluty światowej, nadzorowanie wszelkich terytoriów, gdzie akumulowany jest kapitał, przez wściekłe psy kompleksu wojskowo-przemysłowego, sojusz dwóch fundamentalizmów: rynkowego i religijnego - oto brzemię spoczywające na barkach ubogich tego świata łamiace ich ducha" ${ }^{\prime 5}$.

\footnotetext{
${ }^{49}$ P. McLaren, Życie w szkołach. Wprowadzenie do pedagogiki krytycznej, przeł. A. Dziemianowicz-Bąk, J. Dzierzgowski, M. Starnawski, Wydawnictwo Naukowe Dolnośląskiej Szkoły Wyższej, Wrocław 2015, s. 329377.

50 Tamże, s. 381.
} 
Cała ta eskalująca napięciem i cierpieniem sytuacja domaga się zmian i lewica, jeśli w ogóle zależy jej na tym, żeby występować w obronie ludu uciskanego przez neoliberalną maszynerię powinna chociaż spróbować zmienić zaistniały porządek rzeczy. Stworzyć realną alternatywę, obalić pasożytniczy kapitalizm i transformować, przemienić będącą w kryzysie demokratyczną teorię i praktykę wykorzystując wykluczone dotąd potencjały intelektualne marksowskiej tradycji. Zakończę słowami, które nie spodobają się tym, którzy pomijają milczeniem katastrofalną sytuację wykluczonego ludu. Są to słowa L.A Blanquiego, człowieka, który nie wahał się wprowadzać idei w czyn i walczył o nie do samego końca: „Trudno zaprzeczyć tak oczywistej rzeczy, że nieuniknionym ukoronowaniem cywilizacji jest ustrój wspólnoty. Studia nad przeszłościa i teraźniejszościa dowodza, że każdy postęp jest krokiem na tej drodze, a analiza spornych problemów wspótczesności nie pozwala znaleźć dla nich innego rozsądnego wyjścia. Wszystko wyraźnie zmierza ku temu rozwiązaniu. Ono zaś zależne jest jedynie od oświaty publicznej, a w konsekwencji od naszej dobrej woli. Komunizm nie jest więc utopia. Wyplywa on $z$ normalnego rozwoju"s1.

\section{Bibliografia:}

Agnosiewicz M., Kościół a faszyzm. Anatomia kolaboracji, Wydawnictwo racjonalista.pl, Wrocław 2009.

Blanqui L.A., Wybór pism, przeł. I. Bibrowska, B. Wścieklica, red. A. Baranowska, RSW „Prasa”, „Książka i Wiedza”, Warszawa 1975.

Bikont A., My z Jedwabnego, Wydawnictwo Czarne, Wydanie II, Wołowiec 2012.

Badiou A., Etyka, przeł. P. Mościcki, Wydawnictwo Krytyki Politycznej, Warszawa 2009

Carl Schmitt. Wyzwanie polityczności, red. Ch. Mouffe, Wydawnictwo Krytyki Politycznej, Warszawa 2011.

Co dalej z demokracją?, red. P. Wielgosz, przeł. M. Kowalska, Instytut Wydawniczy Książka i Prasa, Warszawa 2012.

Hochschild A., Duch króla Leopolda. Opowieść o chciwości, terrorze i bohaterstwie w kolonialnej Afryce, przeł. P. Tarczyński, Wydawnictwo Weltbild/Świat Książki, Warszawa 2012.

Krastew I., Demokracja: przepraszamy za usterki, przeł. M. Sutowski, Warszawa 2015.

Leder A., Relacja folwarczna, link do pełnego artykułu na stronie Krytyki Politycznej: http://krytykapolityczna.pl/kraj/leder-relacja-folwarczna/ (dostęp 05.04.2017).

McLaren P., Życie w szkołach. Wprowadzenie do pedagogiki krytycznej, przeł. A. Dziemianowicz-Bąk, J. Dzierzgowski, M. Starnawski, Wydawnictwo Naukowe Dolnośląskiej Szkoły Wyższej, Wrocław 2015.

\footnotetext{
${ }^{51}$ L.A. Blanqui, Krytyka ..., [w] Wybór pism, dz. cyt., s. 342.
} 
Mouffe Ch., Polityczność. Przewodnik Krytyki Politycznej, przeł. J. Erbel, Wydawnictwo Krytyki Politycznej, Warszawa 2008.

Mouffe Ch., Agonistyka. Polityczne myślenie o świecie, przeł. B. Szelewa, Wydawnictwo Krytyki Politycznej, Warszawa 2015.

Raport Komisji Weneckiej w całości, część I: http://www.tvn24.pl/wiadomosci-z-kraju,3/przeczytajcala-opinie-komisji-weneckiej,626862.html (dostęp 08.04.2017).

Część II: http://www.tvn24.pl/wiadomosci-z-kraju,3/przeczytaj-cala-opinie-komisji-weneckiej-czesc-2,626871.html (dostęp 08.04.2017).

Schmitt C., Teologia polityczna i inne pisma, przeł. M.A. Cichocki, Wydawnictwo Aletheia, Warszawa 2012.

Schmitt C., Legalność i prawomocność, przeł. B. Baran, Wydawnictwo Aletheia, Warszawa 2015.

Schmitt C., Lewiatan w teorii państwa Thomasa Hobbesa, przeł. M. Falkowski, Prószyński I S-ka, Warszawa 2008 .

Stiglitz J.E., Cena nierówności w jaki sposób dzisiejsze podziały społeczne zagrażaja naszej przyszłości, Krytyka Polityczna, Warszawa 2015, wersja mobi.

Sloterdijk P., Musisz życie swe odmienić, przeł. J. Janiszewski, PWN, Warszawa 2014.

Sowa J., Fantomowe ciało króla. Peryferyjne zmagania z nowoczesna formą, UNIVERSITAS, Kraków 2011.

Śliwerski B., Edukacja (w) polityce. Polityka (w) edukacji, Oficyna Wydawnicza „Impuls”, Kraków 2015.

Tormey S., Townshend J., Od teorii krytycznej do postmarksizmu, PWN, Warszawa 2010.

Žižek S., Lacan. Przewodnik Krytyki Politycznej, przeł. J. Kutyła, Wydawnictwo Krytyki Politycznej, Wydanie II rozszerzone, Warszawa 2010.

S. Žižek, The Need To Censor Our Dreams: https://www.youtube.com/watch?v=zBbwruvfFR4 (dostęp 08.04.2017).

http://biznes.onet.pl/wiadomosci/kraj/beda-podwyzki-dla-funkcjonariuszy-i-pracownikow-sluzbod-2017-r/dmv3bn (dostęp 08.04.2017). 